\title{
Television and the Public Interest
}

\section{Citation}

Cass R. Sunstein, Television and the Public Interest, 88 Calif. L. Rev. 499 (2000).

\section{Published Version}

http://scholarship.law.berkeley.edu/californialawreview/vol88/iss2/9/

\section{Permanent link}

http://nrs.harvard.edu/urn-3:HUL.InstRepos:13015047

\section{Terms of Use}

This article was downloaded from Harvard University's DASH repository, and is made available under the terms and conditions applicable to Other Posted Material, as set forth at http:// nrs.harvard.edu/urn-3:HUL.InstRepos:dash.current.terms-of-use\#LAA

\section{Share Your Story}

The Harvard community has made this article openly available.

Please share how this access benefits you. Submit a story.

\section{Accessibility}




\section{California Law Review}

Volume 88 | Issue 2

Article 9

March 2000

\section{Television and the Public Interest}

Cass R. Sunstein

Follow this and additional works at: http://scholarship.law.berkeley.edu/californialawreview

\section{Recommended Citation}

Cass R. Sunstein, Television and the Public Interest, 88 CAL. L. Rev. 499 (2000).

Available at: http://scholarship.law.berkeley.edu/californialawreview/vol88/iss2/9

This Article is brought to you for free and open access by the California Law Review at Berkeley Law Scholarship Repository. It has been accepted for inclusion in California Law Review by an authorized administrator of Berkeley Law Scholarship Repository. For more information, please contact jcera@law.berkeley.edu. 


\title{
Television and the Public Interest
}

\author{
Cass R. Sunstein $\dagger$
}

\section{TABLE OF CONTENTS}

Introduction

I. History, Puzzles, Problems .............................................................506

A. A Brief Historical Overview .................................................506

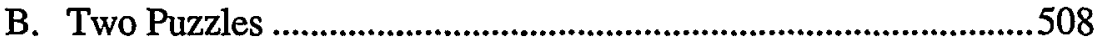

C. Identifying the Proble1n ............................................................509

II. Preferences and Audiences .......................................................5. 511

A. Three Market Failures .............................................................514

1. Eyeballs as the Commodity...............................................514

2. Informational Cascades and Broadcaster

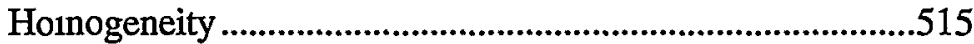

3. Externalities and Collective Action Problems .....................516

B. Problems on Nonmarket Criteria: Children, Deliberative

Democracy, and Related Issues...............................................518

1. Children and the Hearing Impaired...................................518

2. Balkanization ..............................................................519

\section{Copyright $\odot 2000$ California Law Review, Inc.}

$\dagger \quad$ Karl N. Llewellyn Distinguished Service Professor, University of Chicago, Law School and Department of Pohtical Science. From 1997 to 1998, the author served on the Advisory Committee on the Public Service Obligations of Digital Television Broadcasters, which produced a report in December 1998 on which this Article draws. See Advisory Committee on Public InTEREst Obligations of Digital Television Broadcasters, Charting the Digital Broadcasting Future: Final Report of the Advisory Commitiee on Public Interest Obligations of Digital Television Broadcasters (1998). Many of the arguments in this Article were framed through the opportunity to see, through work on the Advisory Committee, two groups close up. The first was a large number of broadcasters-most of them public-spirited, most of them extremely nervous about growing competition from cable and elsewhere, most of them sharply opposed to govcrnment mandates, few of them unwilling to accept governmental help. The second was the National Association of Broadcasters (NAB) -at the time an extraordinarily defensive, fearful, uncooperative, aggressive, and self-protective organization, consisting of many honorable people, but often unwilling to compromise or even to reflect. In this way, the NAB was reminiscent of the tobacco industry in, say, the 1960s, and was enthnsiastic abont using the First Amendment im the same way that the National Rifle Association uses the Second Amendment, that is, as an all-purpose shield against any action adverse to their interests. The author is grateful to other members of the Advisory Committee for many helpful discussions of these problems and, in particular, to the two co-chairs of the Committee, Norman Ornstein and Leslie Moonves. The Committee's final report has influenced the treatment here, not least when there are disagreenents. He is also grateful, for helpful comments, to Douglas Lichtman, Eric Posner, and Richard Posner, and to participants in a conference held in honor of Jürgen Habermas in Frankfurt, Germany in July 1999, especially Clause Offe, Bernhard Peters, and Jürgen Habermas. 
3. Citizens, Consumers, and Precommitment Strategies...................................................................520

4. Endogenous Preferences ..................................................521

5. Paternalism? Elitism?.....................................................522

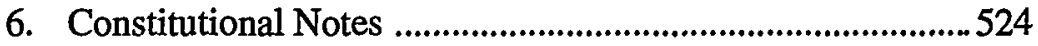

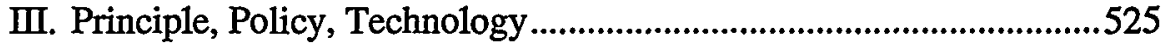

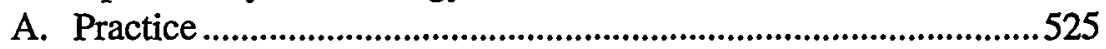

B. Commumications Past, Present, and Future: Planned

Obsolescence and Beyond .......................................................5.526

1. Predicting the Future .......................................................5527

2. Regulatory Options and Technological Clange ..................529

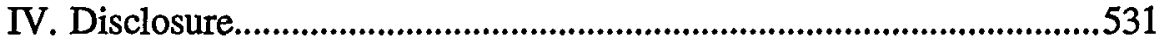

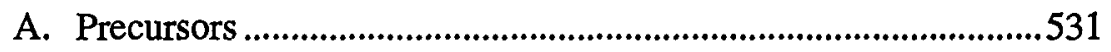

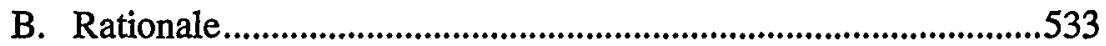

C. The Minimal Proposal ...........................................................535

D. Of Realism and Ineffectiveness..............................................536

V. Economic Incentives .................................................................538

A. Of Nature and Coase ...............................................................538

B. Taxes, Public Bads, Hot Potatoes, and Cold Spots .....................539

C. Economic Incentives and the Constitution ..............................5.542

D. Expanding the Viewscreen: A Glance at the Cathedral ..............543

E. A Brief Note on Cultural Policies and

Cultural Subsidies..........................................................................549

VI. Voluntary Self-Regulation: Aspirations, Trustees, and "Winner-Take-Less" Codes

A. The Problem and a Recently Emerging Strategy .....................551

B. A Code: Sample Provisions.....................................................553

C. A Code: Problems and Prospects ...........................................555

D. Notes on the First Amendment and Antitrust Law.....................557

F. Less Puzzling Puzzles ..........................................................558

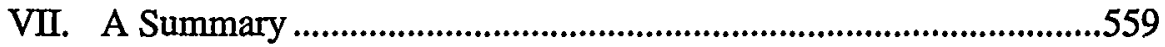

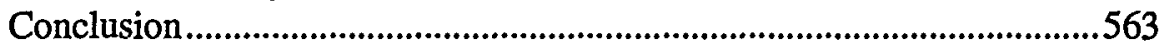




\title{
Television and the Public Interest
}

\author{
Cass R. Sunstein
}

The communications revolution has thrown into question the value of imposing public interest obligations on television broadcasters. But the distinctive nature of this unusual market-with "winner-take-all" features, with viewers as a commodity, with pervasive externalities from private choices, and with market effects on preferences as well as the other way around-justifies a continuing role for government regulation in the public interest. At the same time, regulation best takes the form, not of anachronistic command-and-control regulation, but of (1) disclosure requirements, (2) economic incentives ("pay or play"), and (3) voluntary selfregulation through a privately administered code. Some discussion is devoted to free speech and antitrust issues, and to the different possible shapes of liability and property rules in this context, treating certain programming as a public "good" akin to pollution as a public bad.

\section{INTRODUCTION}

There is a large difference between the public interest and what interests the public. This is so especially in light of the character and consequences of the communications market. One of the central goals of the systent of broadcasting, private as well as public, should be to proinote the American aspiration to deliberative democracy, ${ }^{1}$ a systen in which citizens are informed about public issues and able to make judginents on the basis of reasons. Both norms and law should be enlisted in this endeavor; if one fails, the other becoines all the inore important. These are the claims that I attempt to bring to bear on the so-called communications revolution.

This revolution has been driven by extraordinary technological change. ${ }^{2}$ The rise of cable television, the Internet, satellite television, direcTV, and digital television has confounded ordinary understandings of "television." Before long, digital television may enable viewers to choose

1. See, e.g., Amy Gutmann \& Dennis Thompson, Democracy and Disagreement 52-94 (1996) (discussing ideals of deliberative democracy); Joshua Cohen, Democracy and Liberty, in Deliberative DemocRacy 185, 185-231 (Jon Elster ed., 1998) (discussing foundations of deliberative deinocracy).

2. A valuable general discussion can be found in ANDREw L. SHAPIRo, THE Control ReVolution (1999).

3. See Bruce M. Owen, The Internet Challenge to Television 311-26 (1999) (dealing with other dramatic technological developments). 
among over a thousand programs. ${ }^{4}$ The possible combination of television and the Internet, a combination now in its early stages, may prove an equally dramatic development; the fact that the Internet is a partial substitute for television has already introduced a measure of competition between the two. ${ }^{5}$

Law has responded to these developments in fits and starts, largely by attempting to engraft legal requirements designed for the old environment onto an altogether new communications market. The result is a high degree of anachronism, misfit, and drift, and in the view of many observers, a series of constitutional violations. ${ }^{6}$ Most of the modern debate involves a vigorous but increasingly tired contest between those defending the old regulatory order" and those urging rapid movement toward "smiple rules" for government control of television, above all well-defined property rights and freedom of contract. ${ }^{8}$ Strikingly similar debates, about the value of "simple rules," the place of regulatory safeguards, and the role of television in a democracy, can be found im inany nations. ${ }^{9}$

My aim in this Article is to discuss an miportant part of the intersection between the einerging communications market and law: public interest obligations imposed on television broadcasters. ${ }^{10}$ Since the initial rise of broadcasting in the United States, government has treated the license as a kind of "grant" that is legitimately accoinpanied by duties." Congress and the FCC have required broadcasters to follow a range of requirements-a form of old-style "command-and-control" regulation, growing out of an

4. See Lawrie Mifflin, As Band of Channels Grows, Niche Programs Will Boom, N. Y. Times, Dec. 28, 1998, at A1.

5. See OWEN, supra note 3, at 311-26. But see David Goldberg et al., Conclusions, in Regulating the Changing Media: A Comparative Study 295, 297 (David Goldberg et al. eds., 1998) (" $[C]$ onvergence has been unequal between different nations, has been slower than expected and will not break down distinctions between different markets as rapidly as is claimed.").

6. See Rationales \& Rationalizations: Regulating the Electronic Media (Robert Corn-Revere ed., 1997); Thomas G. Krattenmaker \& L.A. Powe, Jr., Converging First Amendment Principles for Converging Communications Media, 104 YALE L.J. 1719, 1725 (1995); Mark S. Fowler \& Daniel L. Brenner, A Marketplace Approach to Broadcast Regulation, 60 TEX. L. REV. 207, 209-10 (1982).

7. This seems to me the general thrust of LeE C. Bollinger, IMAGES OF a Free Press (1991) and OWEN M. Fiss, The IrONY OF FREe SPEech (1996).

8. See Richard A. Epstein, Simple Rules for a COMPlex World 275-306 (1995) (discussing environmental protection and presenting a general account of the role of government in a way that is easily adapted to the area of communications); RATIONALES AND RATIONALIZATIONS, supra note 6 (offering a number of essays challenging any role for government aside from the definition and enforcement of property rights).

9. See Monroe E. Price, Television: The Public Sphere and National Identity (1995); Goldberg et al., supra note 5.

10. I use this term to refer to literal broadeasters, and thus not to include cable providers. As we will see, however, the distinction between the two seems increasingly (though not yet entirely) artificial, and much of the discussion will bear on the appropriate regulatory stance toward television in general.

11. See discussion infra Part I.A. 
understanding that there would be three, and only three, private broadcasting stations. Much, though far from all, of this regulation was eliminated in the $1980 \mathrm{s.}^{12} \mathrm{~A}$ large question is the extent to which public interest requirements continue to unake sense, or even to survive constitutional scrutiny, in an entirely different communications inarket where broadcasters occupy a decreasingly distinctive position.

The question was posed starkly with the enactment of the Telecommunications Act of $1996,^{13}$ one of whose central concerns involved the rise of digital television. The Act had to deal with two issues. First, who would have the right to broadcast digital television? Should the licenses be sold, or auctioned, or given outright to existing broadcasters? Second, what public interest obligations, if any, should attach to the ownership of a right to broadcast digital television? The Act squarely answered the first question, ${ }^{14}$ but was inconclusive on the second. In an extrenely controversial step, Congress did not sell or auction the right to broadcast digital television, but basically gave the right to existing broadcasters for free. ${ }^{15}$ This has been described, and reasonably so, as a "huge giveaway" of "a $\$ 70$ billion national asset." 16 At the same time, Congress refused to eliminate public interest obligations, delegating to the FCC the power to decide whether such obligations should be imposed on digital television broadcasters, and if so, in what form. ${ }^{17}$ The FCC has not yet unade that decision or even commenced formal proceedings.

In this Article, I offer two basic claims, one involving ends, the other involving means. The first is that in view of the character and consequences of television programming, any system for the regulation of television should be evaluated in dexnocratic as well as economic terms. The economic ideal of "consumer sovereignty" is ill-suited to the communications nnarket. It follows that, at least in the near term, the changes introduced by the emerging commumications systeen do not justify abandoning the idea that broadcasters should be required to promote public interest goals. Educational programming and programming that deals with civic questions can promote the aspiration to deliberative democracy; reliance

12. See id.

13. Pub. L. No. 104-104, 110 Stat. 56 (codified in scattered sections of 47 U.S.C. $\$ \S 151-613$ (Supp. III 1997)) (amending the Communications Act of 1934).

14. See 47 U.S.C. $\$ 336($ a).

15. See id.

16. What Price Digital Television?, N.Y. TimEs, Dec. 26, 1998, at A26; see also Federal Management of the Radio Spectrum: Advanced Television Services: Hearing Before the Subcomm. on Telecomm. and Fin. of the House Comm. on Commerce, 104th Cong. 82 (1996) (statement of Robert M. Pepper, Chief, Office of Plans and Policy, FCC) (stating that an auction would bring between $\$ 11$ to $\$ 70$ billion in revenue). For general criticism, see Thomas $\mathrm{G}$. Krattenmaker, The Telecommunications Act of 1996, 29 ConN. L. REv. 123, 163-64 (1996), and Matthew Spitzer, Dean Krattenmaker's Road Not Taken: The Political Economy of Broadcasting in the Telecommunications Act of 1996, 29 ConN. L. REv. 353 (1996).

17. See 47 U.S.C. § 336(d). 
on an unregulated market may not. There are also legitimate grounds for encouraging broadcasters to make programming accessible to people with disabilities, above all the hearing impaired. I emphasize in this connection some special characteristics of the broadcasting market, characteristics that make it hazardous to rely on "consumer sovereiguty" as the exclusive basis for regulatory policy. Instead commumications policy should be assessed, at least in part, by reference to its effects on the public sphere. ${ }^{18}$

My second claim is that im order to promote the relevant goals, government should decreasingly rely on command-and-control regulation, ${ }^{19}$ and should consider instead three less intrusive and more flexible instruments, eacl of which is well-adapted to a period of rapid technological change. The instruments are: (1) mandatory public disclosure of information about public interest broadcasting, unaccompanied by content regulation; (2) economic incentives, above all subsidies and "play or pay"; and (3) voluntary self-regulation, as through a "code" of appropriate conduct, to be created and operated by the industry itself. These instruinents have played an increasing role in regulatory policy in general, especially in the environmental arena. ${ }^{20} \mathrm{But}$ they have rarely been discussed in the area of commumications, where they have a natural place, ${ }^{21}$ and despite its growing importance, the general topic of industry self-regulation has received little academic attention. ${ }^{22}$

By requiring broadcasters to disclose information about their public interest activities, the government might be able to enlist public pressure and social norms so as to create a kind of competition to do inore and better. This is the simplest and least intrusive of regulatory instruments. By allowing broadcasters to buy their way out of certain public interest obligations, the government should be able to ensure that those with an

18. See Price, supra note 9, at 194-246. See generally Jürgen Habermas, The Structural Transformation of the Public Sphere (Thomas Burger trans., 1989) (offering an extended historical discussion).

19. A question not addressed here is the content of any minimal requirements; $I$ emphasize the more flexible alternatives as the instruments of choice, without denying the need for some minima as a "backstop." In the current system, for example, it may well make sense to require a degree of children's programming and also free air time for candidates. See ADvisory CoMmiTteE ON PUBLIC INTEREST Obligations of Digital Television Broadcasters, Charting the Digital Broadcasting Future: Final Report of the Advisory Committee on Public Interest Obligations of Digital TElevision Broadcasters 45-64 (1998) [hereinafter Final REPORT]. The precise extent of mandatory programming is beyond the scope of the present discussion, though I do refer to mandates at several points below.

20. See generally NeIl GunNingham et al., SMart Regulation: Designing Environmental Policy 422-48 (1999); National ACad. of Pub. Admin., The Environment Goes To Market 9-20 (1994); ANthony Ogus, Regulation 121-49, 245-56 (1998).

21. The best discussion can be found in Angela J. Campbell, Self-Regulation and the Media, 51 FED. COMM. L.J. 711 (1999).

22. The principal exception can be found in an illuminating symposium issue in an Australian law review. See Symposium, Special Issue on Self-Regulation, 19 LAW \& PoL'y 363 (1997) [heremafter Special Issue on Self-Regulation]. 
incentive to produce good programming are actually doing so, while also producing the lowest-cost ineans of proinoting public interest programming. And by encouraging (not mandating) voluntary self-regulation, the government can help overcome a kind of prisoner's dilemma faced by participants in a "winner-take-all" inarket, ${ }^{23}$ a prisoner's dilemma that contributes to a range of social probleins, often stemming from a kind of "race to the bottom" with respect to programming quality.

It should be clear that this basic approach combines a recognition of the serious limits of unrestrained communications markets in promoting social goals with a plea for rejecting traditional regulation and for enlisting inore flexible, inarket-oriented instruments in the service of those goals. This approach is consistent with sone incipient but quite general trends in regulatory law. ${ }^{24}$ If the approach is sound, it is well-suited to the emerging communications narket; but it is easily adapted to other areas as well, including environmental degradation, occupational safety and health, and other social problems. It is inuch too soon to say whether there is a "third way" between traditional command-and-control regulation and reliance on free trade and well-defined property rights. ${ }^{25}$ But if there is indeed a "third way," it is likely to be found in proposals of this kind.

A general theme of this Article is that disclosure, economic incentives, and voluntary self-regulation might displace government coininandand-control in a variety of areas of regulatory law. Specific thenes include requiring producers simply to disclose goods and bads; relaxing antitrust law so as to permit cooperation designed to reduce soine of the problens associated with "races to the bottoin"; and building on einerging developments in environmental protection so as to allow far more imaginative "trades" among producers. In short, it is time to inove beyond the view that market ordering and content regulation are the only two possibilities for communications law. There are many alternatives, and real progress can coine only froin exploring the choices among then.

The Article coines in seven parts. Part I sets the stage, outliming the history of regulation, identifying some relevant puzzles, and exploring some diverse probleins with television in its current forn. Part II, the theoretical heart of the Article, evaluates and rejects the clain that in the ennerging media market there is no longer room for public interest regulation of any kind. I suggest that television is no ordinary commodity, partly

23. See Robert H. Frank \& Phillip J. Cook, The Winner-Take-All Society 189-209 (1995). The most important distinguishing feature of "winner-take-all" markets is that rewards are based on "relative rather than (or in addition to) absolute performance." Id. at 24. In such markets, "rewards tend to be concentrated in the hands of a few top performers." II.

24. See, e.g., GunNingham et AL., supra note 20, at 37-91; NAtional ACAD. of Pub. AdMin., supra note 20; Cass R. Sunstein, Informational Regulation and Informational Standing: Akins and Beyond, 147 U. PA. L. REv. 613, 618-33 (1999).

25. For a general discussion, see ANTHONY GIDDENS, THE THIRD WAY (1998). 
because of the collective benefits of good programming, partly because of the link between television and democracy, and partly because viewers are more like products offered to advertisers than consumers paying for entertainment on their own. Part III discusses the relation between principle and practice; it traces likely stages of the emerging market, with broadcast programming becoming increasingly like general-interest magazines. Part IV deals with disclosure, exploring the possibility that relevant private groups, invoking widespread social norms, can interact to produce improvements in the broadcasting market without compulsory programming of any kind. Part $\mathrm{V}$ deals with economic incentives, beginning with the idea of "play or pay," and then adapting some ideas from the law of tort to the law of broadcasting. Part VI examines whether a code of broadcasting might operate as a kind of positional arms control agreement, helping to counteract a situation in which broadcasters compete to the detriment of collective goals. Part VII is a brief summary of regulatory options.

I

History, Puzzles, Problems

A. A Brief Historical Overview ${ }^{26}$

Broadcast licenses have never been treated like ordinary property rights, open for sale on the free market. ${ }^{27}$ Since the imitial enactment of the Communications Act of 1934, the government has awarded licenses to broadcasters in accordance with "convenience, public interest, [and] necessity." 28 The Federal Radio Commission early described the system as one in which broadcasters "must be operated as if owned by the public. ... It is as if a community should own a station and turn it over to the best man in sight with this injunction: 'Manage this station in our interest. . .." 29 Under this "public trustee" standard, the FCC has iniposed a range of obligations on broadcasters-an idea that perhaps made special sense when a small number of companies dominated the television market.

In its initial set of guidelines, the FCC required stations to meet the "tastes, needs, and desires of all substantial groups annong the listening public ...."30 This required "a well-rounded program, in which

26. This Section draws on the first section of the FINAL REPORT, supra note 19, at 3-16. See also Campbell, supra note 21, for detailed discussion of many relevant developments.

27. See the colorful, skeptical presentation in Peter Huber, LAW AND Disorder IN Cyberspace: Abolish the FCC and Let Common Law Rule the Telecosm 3-9 (1997).

28. 47 U.S.C. $\$ 303$ (1994).

29. The Federal Radio Commission and the Public Service Responsibility of Broadcast Licensees, 11 FED. COMM. BAR J. 5, 14 (1950) (quoting Schaeffer Radio Co., an unpublished 1930 Federal Radio Commission decision).

30. Great Lakes Broadcasting Co., 3 Fed. Radio Comm'n, Ann. Rep. 32, 34 (1929), modified on other grounds, 37 F.2d 993 (D.C. Cir. 1930). 
entertainment, consisting of music of both classical and lighter grades, religion, education and instruction, important public events, discussions of public questions, weather, market reports, and news, and matters of interest to all members of the family, fimd a place."31

Often this kind of guidance operated as a general plea, with little systematic enforcement. In 1960, however, the FCC went so far as to outline fourteen of the "major elements usually necessary to meet the public interest." 32 These included: religious programming, programs for children, political broadcasts, news programs, sports programs, weather and market services, and development and use of local talent. ${ }^{33}$ The FCC eventually specified its general guidelines, which were merely indicia of the types and areas of appropriate service. The specifications included minimum amounts for news, public affairs, and other nonentertainment programming, including the controversial "fairness doctrine" 34 and also access rules for prime-time..$^{35}$

Substantial changes occurred in the 1980 s, a period of significant deregulation. The head of the FCC, Mark Fowler, declared (in a kind of soundbite, or bumper-sticker, for the market approach to the topic) that television is "just another appliance," a "toaster with pictures." fairness doctrine was largely eliminated, and many of the more particular public interest requirements were removed ${ }^{37}$ Nonetheless, a number of such requirements remain. For example, the FCC continues to say that if a broadcaster sells airtime to one candidate, it must sell similar time to opposing candidates as well. Congress itself lras codified a right of this kind.$^{38}$ A long-standing statutory provision, in the obvious self-interest of law makers, requires that if a broadcaster offers to sell time, it must do so at the "lowest unit rate of the station" during the forty-five days before a

31. Id.

32. Report and Statement of Policy Res: Commission en banc Programming Inquiry, 44 F.C.C. 2303,2314 (1960).

33. See id.

34. In brief, the faimess doctrine required broadcasters to attend to public issues and to ensure a diversity of views. On the doctrine, see discussion infra Part III.A.

35. See Amendment to Section $\mathbf{0 . 2 8 1}$ of the Commission's Rules: Delegations of Authority to the Chief, Broadcast Bureau, 59 F.C.C.2d 491, 493 (1976); Amendment of Part 73 of the Commission's Rules and Regulations with Respect to Competition and Responsibility in Network Television Broadcasting, 23 F.C.C.2d 382, 385-88 (1970).

36. Bernard D. Nossiter, Licenses to Coin Money: The F.C.C.'s Big Giveaway Show, 241 NATION 402 (1985) (quoting radio address given by Mark Fowler).

37. See The Revision of Programming and Commercialization Policies, Ascertainment Requirements, and Program Log Requirements for Commercial Television Stations, 98 F.C.C.2d 1076 (1984); see also Revision of Applications for Renewals, 49 R.R.2d 470 (1981) (postcard renewals); Syracuse Peace Council v. Television Station WTVH, 2 F.C.C. Rcd. 5043, 5054-55 (1987) (repealing most of fairness doctrine), aff'd sub nom. Syracuse Peace Council v. FCC, 867 F.2d 654 (D.C. Cir. 1989).

38. See 47 U.S.C. § 315 (1994). 
primary election and during the sixty days before a general or special election. ${ }^{39}$

In recent years Congress has devoted special attention to children's programming and to television access for the hearing impaired. In 1990, Congress enacted the Children's Television Act of $1990,{ }^{40}$ limiting the advertising on children's programming (twelve minutes per hour during weekdays and ten and a half minutes per hour on weekends). ${ }^{41}$ Under this statute, the FCC has further required broadcasters to provide three hours of children's programming per week. ${ }^{42}$ The Television Decoder Circuitry Act of $1990^{43}$ requires new television sets to have special decoder chips, allowing them to display closed-captioned television transmissions for the hearing impaired. The Telecommunications Act of $1996^{44}$ requires use of "v-chip" technology, designed to facilitate parental control over what enters the hone; it also contains ancillary requirenents intended to ensure "ratings" of programming content. ${ }^{45}$

\section{B. Two Puzzles}

Turn now to the present, or at least to the niore recent past. From 1997 to 1998 , a presidential advisory committee met to discuss the public interest obligation of television broadcasters. ${ }^{46}$ Several of the broadcasters on the Committee were quite skeptical about governmental mandates, but highly receptive to the idea of adopting sonje kind of broadcasting "code," akin to the kind approved and administered by the National Association of Broadcasters (NAB) between 1928 and 1979.47 The Committee eventually nuoved toward endorsing the notion of a code, and the idea received considerable attention in the trade press. ${ }^{48}$

In its annual neeting, however, the NAB signaled skepticism about the idea and came very close to saying "no" and "never." A large part of the broadcasters' objection was that any "code" would violate the antitrust laws. This was very odd because in their discussions, meinbers of the NAB

39. Id. § 315(b).

40. Pub. L. No. 101-437, 104 Stat. 996 (codified in scattered sections of 47 U.S.C.).

41. See 47 U.S.C. \$ 303(a) (1994).

42. See Broadcast Services: Children's Television, 61 C.F.R. $\S 43981,43988$ (1996).

43. 47 U.S.C. $\S 303(\mathrm{u})$.

44. Pub. L. No. $104-104,110$ Stat. 56 (codified in scattered sections of 47 U.S.C. $\$ \S 151-613$ (Supp. III 1997)).

45. See the general discussion in James T. Hamilton, Channeling Violence: The Economic Market for Violent Television Programming 302-11 (1998).

46. I draw on personal recollections here. See FINAL REPORT, supra note 19. Transcripts of the relevant meetings can be found on the web site of the Advisory Committee on the Public Interest Obligations of Digital Television Broadcasters at <http://www.ntia.doc.gov/pubintadvcom/piacreport. pdfs.

47. See discussion infra Part V.B; see also Campbell, supra note 21, at 720-35.

48. See, e.g., Gore Proposals Go to White House, Television Digest, Dec. 21, 1998.; Gore Recommendations on Digital Standards Go to White House, COMM. DAILY, Dec. 21, 1998. 
treated the possibility of an antitrust violation as extremely good news. Take this as the first puzzle; it is not often that high-level corporate officials are smiling when they discuss the possibility that their own action would be found unlawful.

Consider a second puzzle. During the committee's deliberations, some people argued on behalf of a "play or pay" system, in which broadcasters would be relieved of public interest obligations (to "play") if they agree instead to "pay" someone else-another broadcaster-to do so. But many of the broadcasters on the committee were quite skeptical of this approach, arguing that public interest obligations were part of the (sacred?) duty of every broadcaster, and that no one should be exempted for a price. This was also very odd. It is not often that high-level corporate officials prefer rigid government mandates to more flexible approaches. What explains these puzzles? The answers - offered in closing here ${ }^{49}$-reveal a great deal about the einerging market.

\section{Identifying the Problem}

To evaluate particular proposals, it is necessary to have a concrete sense of why some people think that even well-functioning television markets are inadequate. Consider the following possibilities, each of which has produced public concern in the last decade: ${ }^{.50}$

1. There may be imsufficient educational programming for children. The existing fare inay be insufficient because there is too little simply in terms of amount (for example, for people who lack cable), or because children do not watch the stations on which it is available, or because the quality is too low.

2. Programming may not be sufficiently accessible to people who are hearing impaired; this may be a particular problem if citizens are unable to find out about emergencies, or if they are unable to understand programming that bears on central public issues. ${ }^{51}$ The exclusion may have practical consequences; it may even produce a form of humiliation. ${ }^{52}$

3. At least on the major networks, programming may be too homogenous, in a form of "blind-leading-the-blind" programming. Since a significant percentage of Americans do not receive

49. See infra Part IV.F.

50. For different angles, see, for example, Final REPORT, supra note 19; HAMLton, supra note 45, at 3-50 (discussing television violence as a public policy issue); NEWTON N. MINOW \& CRAIG L. LaMay, Abandoned in the Wasteland: Children, Television, and the First Amendment 1045 (1995) (arguing that the system scrves the best interests of advertisers rather than children); DANNY SCHEchter, The More You Watch, The Less You KNOW (1997) (examining the content of news).

51. See Final RePORT, supra note 19, at 30-31.

52. On the notion of liumiliation, see Avishat Margalit, The Decent Society (Naomi Goldblum trans., 1996). 
cable television and depend on broadcasters, the result may be insufficient variety in programming. ${ }^{53}$

4. Some programming may be affirmatively bad for children if, for example, it contains excessive violence, or otherwise encourages behavior that is dangerous to self and others. The result of such programming may be to produce violent or otherwise dangerous behavior in the real world. ${ }^{54}$

5. There may be too much violent programming in general, with adverse consequences for adults, not only children.5.$^{55}$ The adverse consequences may include an increase in violence (because of changes in social norms or "copycat" effects ${ }^{56}$ ), general demoralization and fear, or a misperception of reality.

6. News coverage may be a form of "infotainment," dealing not with real issues, but with gossip about celebrities and unsubstantiated charges of various kinds. ${ }^{57}$

7. There may be too little coverage of serious questions, especially during political campaigns. The relevant coverage may involve sensationalism and "sound bites," or attention to who is ahead ("horse-race issues") rather than who thinks what and why. The result may be an insufficiently informed citizenry. ${ }^{58}$

8. Stations too rarely cover international issues or developments in other nations. The result is that people are extremely ill-informed about the global background for national events, including proposed financial assistance and possibly even war, and also about practices other than their own. This ignorance makes it difficult

53. See discussion infra Part II.A.2.

54. See HamLton, supra note 45 , at $20-30$, for evidence.

55. See id. (providing a detailed discussion).

56. For evidence, see Ellot Aronson, THE Social ANIMAL 62-64, 263-67 (6th ed. 1992).

57. See generally ScHECHTER, supra note 50.

58. See KiKu AdatTo, Sound-Bite Democracy (1990), for general discussion; and JohN Dewey, The Public and its Problems: AN Essay in Political Inquiry 179-80 (Gateway Books 1946) (1927):

A glance at the situation shows that the physical and external means of collecting information in regard to what is happening in the world have far outrun the intellectual phase of inquiry and organization of its results. Telegraph, telephone, and now the radio, cheap and quick mails ... have attained a remarkable development. But when we ask what sort of material is recorded and how it is organized, when we ask about the intellectual form in which the material is presented, the tale to be told is very different. "News" signifies something which has just happened, and which is new just because it deviates from the old and regular.... [W] have here an explanation of the triviality and "sensational" quality of so much of what passes as news. The catastrophic, namely, crime, accidents, family rows, personal clashes and conflicts, are the most obvious forms of breaches of continuity ... they are the new par excellence.... 
for people to deliberate well about important questions and evaluate purely national practices. ${ }^{59}$

9. It may be too expensive for candidates to reach the electorate via television. The result may be excessive competition to accumnlate funds simply in order to have access to television; this competition may have corrosive effects on the electoral process. Free air time would be a possible response, perhaps qualified by an obligation, on the part of the candidate, to speak for at least fifty percent of the time or to refrain from negative campaigning.

10. There may be too little substantive diversity of view-too little debate annong people with genuinely different perspectives about issues of policy and fact. Here too, the result may be an insufficiently informed citizenry. ${ }^{60}$

11. The problein may be not homogeneity but heterogeneity, which may result in a highly balkanized viewing public, in which many or most people lack shared viewing experiences, or in which people view programming that largely reinforces their own convictions and prejudices. ${ }^{61}$ The result can be extremism and fragmentation. ${ }^{62}$

To be sure, some of these problems cannot be corrected through regulation that is either feasible or constitutional. Moreover, these various conceptions of the relevant problem point toward diverse solutions, some of which would raise serious First Amendment problems, as discussed below. ${ }^{63} \mathrm{~A}$ particular challenge is to develop approaches that would allow a high degree of flexibility, minimize government involvement in prograinming content, and also do some good.

II

\section{Preferences AND AUdIENCES}

It has increasingly been urged that any objections to existing television are elitist or outmoded ${ }^{64}$ On one view, public interest obligations have no place in modern law, particularly because the "scarcity" rationale for

59. See generally Susan D. Mueller, Lumpussion Fatigue (1999); Martha C. Nussbaum, Cultivating Humanity (1997).

60. See C. Edwin Baker, The Media that Citizens Need, 147 U. PA. L. Rev. 317, 383-408 (1998).

61. See the discussion of oversteering and balkanization in SHAPIRO, supra note 2, at 105-32.

62. See id. See also the discussion of group polarization in Patricia Wallace, The Psychology of The INTERnet 73-78 (1999); David Schkade et al., Are Juries More Erratic than Individuals?, Colum. L. REv. (forthcoming 2000); and Cass D. Snnstein, The Law of Group Polarization (Jan. 3, 2000) (unpublished manuscript) (on file with author).

63. See discussion infra Part II.B.6.

64. See generally HuBER, supra note 27; Fowler \& Brenner, supra note 6. 
regulation grows weaker every day; ${ }^{65}$ it has even been urged that the FCC no longer has any appropriate role. ${ }^{66}$ Once the problem of scarcity has been eliminated, individual consumers can design their own preferred commumications package, at least if the government permits them to do so. Consider this utopian picture of a system of unrestricted markets in commumications:

There will be room enough for every sight and sound, every thought and expression that any human mind will ever wish to convey. It will be a place where young minds can wander in adventurous, irresponsible, ungenteel ways. It will contain not innocence but a sort of native gaiety, a buoyant, carefree feeling, filled with confidence in the future and an unquenchable sense of freedom and opportumity. ${ }^{67}$

A conceptual point first: though many people claim to argue for "deregulation," that route is not in fact an option, or at least not a reasonable one. What "deregulation" really means is a shift from the status quo to a system of different but emphatically legal regulation, more specifically one of property, tort, and contract rights, im which government does not impose specific public interest obligations but instead sets up initial entitlements and then permits trades among owners and producers. This is a regulatory system as much as any other. If it seems close to the current systein for newspapers and magazines, it is no less a regulatory system for that reason; a great deal of law (inevitably) governs the rights and duties of newspapers and magazines. ${ }^{68}$ Such law imposes rights and duties,

65. As noted below, the rationale has not disappeared; well over one-third of American households continue to depend on free, over-the-air broadcasting. See U.S. BUREAU OF THE CENSUS, Statistical ABStract of The United States: 1998 at 573 (118th ed. 1998) (Table No. 915, Utilization of Selected Media: 1970 to 1996). On some of the difficulties with the whole notion of scarcity, see R.H. Coase, The Federal Communications Commission, 2J.L. \& EcoN. 1 (1959). The defect of Coase's analysis is his (remarkable) lack of self-consciousness about the idea that consumer sovereignty is the appropriate ideal for broadcasting; it is as if that idea is so self-evidently correct that it need not even be defended.

66. See HUBER, supra note 27, at 3-9. See also, in a different vein, LAWRENCE LESSIG, CODE AND OTHER LAWS OF CyBERSPACE 188-90 (1999) (argning that a growing body of technical research suggests the FCC is unnecessary); Yochai Benkler \& Lawrence Lessig, Net Gains, THE NEw REPUBLIC, Dec. 14, 1998, at 15 (same).

67. HUBER, supra note 27 , at 206.

68. I do not deal here with the question why broadcasters and newspapers should be subject to different legal regimes. As a matter of fact, the differenee seems to be a historical accident, associated with the particular form of regulation chosen for broadcasting. See id. at 4-9. As a matter of principle, the difference has been justified as a way of ensuring two competing regulatory regimes, each welldesigned to combat the vices associated with the other. See generally BoLLINGER, supra note 7. In my view, this justification is serious but not convincing, and some measures designed to promote a wellfunctioning democratic culture might well be justified as applied to newspapers too. See CASS R. Sunstein, Democracy and the Problem of Free Speech 107-08 (1993). For example, it would not be unconstitutional, in my view, for government to require large metropolitan newspapers to have a "letters to the editor" page, or to require such newspapers to disclose their public service activities, or to require such newspapers to publish, on a nondiscriminatory basis, paid political advertising. For the 
permissions and prohibitions; among other things, it ensures, via the law of property, that some people, and not others, will have access to the public sphere. The issue is thus not whether to "deregulate," but whether one or another regulatory system is better than imaginable alternatives.

Notice that this is a purely conceptual claim; it is not a normative argument of any kind. Any market system necessarily depends on regulatory controls, in the form of an assignment (by law) of property rights and (legal) rules of contract. ${ }^{69}$ A systein of television is hard to imagine without ownership rights; in the absence of ownership rights, who could use whose spectrum for what purpose? It is no answer to point to voluntary arrangements. Such arrangements are likely to break down without rules of law allowing some people to exclude others. If the Columbia Broadcasting System does not have a legal right to own spectrum and to enter into binding agreements with others, it will not be able to provide television as we know it. This point should be a familiar one for land and other "tangible" property; it is no less true for the services provided by television. Indeed, it holds, though to a lesser extent, for those who have web sites and provide services over the Internet; without legal protection against trespasses, and without a right to enter into legally enforceable agreements, web sites would be a inodern version of the state of nature- - a battleground rather than a framework for productive relationships. ${ }^{70}$

I therefore turn to the general question whether there remains any reason for government to regulate television in the "public interest." My concern here is both theoretical and empirical. The question is whether, in the current market, broadcasters are likely to provide viewers what they would like to see, and if so, whether that point is decisive on the question whether public interest obligations should be imposed. ${ }^{71}$ The brief answer is that the idea that broadcasters show "what viewers want" is a quite inadequate response to the argument for public interest obligations. ${ }^{72}$ The discussion

most part, however, such requirements do not seen necessary. But I cannot discuss these issues in detail here.

69. In certain circumstances, norms may successfully do the work of law. See RoBERT C. ELLICKSON, ORDER WITHOUT LAW 46 (1991). But even in such circumstances, legal rules of property and contract generally looin in the background.

70. See Neil W. Netanel, Cyberspace Self-Governance: A Skeptical View from Liberal Democratic Theory, 88 CALIF. L. REv. 395 (2000). Of course it is possible to imagine the Internet as a form of genuine anarchy, unregulated by legal rules, with norms and self-help (in the form of code) doing the work ordinarily done by the law of contract and property. Interestingly, the Internet is not subject to the usual legal realist claim that private ordering is dependent on law and that law is inevitable. See Cass R. Sunstenn, The Partial Constimution 51-54 (1993). But it is very hard to imagine this state of affairs for television, and those most critical of the existing legal structure seek only to replace one legal regime with another. See HuBER, supra note 27, at 5-30.

71. At several points I draw on the superb discussion found in C. Edwin Baker, Giving the Audience What It Wants, 58 Oнто Sr. L.J. 311 (1997).

72. See id. 
here deals with the technological present and the short-term future; later I introduce complications from emerging technological developments.

\section{A. Three Market Failures}

According to the economic model, a well-functioning television market would promote the ideal of consumer sovereignty. On this view, the point of markets is to satisfy consumer preferences. In this system, people would satisfy their "preferences," as these are measured via the criterion of private willingness to pay. People would be able to choose from a range of options, and suppliers would cater to their tastes. To a considerable extent, of course, the existing system already approaches this ideal, and this is increasingly the case. But there are three serious problems, each suggesting that the economic ideal of consumer sovereignty is not in fact served by free markets in programming. These are market failures if it is assumed that the purpose of a well-functioning television market is to ensure that programming is well-matched to viewer preferences. In the next Part, I question the market ideal itself.

\section{Eyeballs as the Commodity}

The first point is the simplest. Currently television is not an ordinary product, for broadcasters do not sell programming to viewers in return for cash. A system of "pay-per-view" would indeed fit the usual commodity model; but "pay-per-view" continues to be a relatively rare practice. The difference between the existing broadcasting market and "pay-per-view" is quite important. The key problem here is that viewers do not pay a price, market or otherwise, for television. As C. Edwin Baker has shown, it is more accurate to say that viewers are a commodity, or a product, that broadcasters deliver to the people who actually pay them: advertisers. ${ }^{73}$

This phenomenon introduces some serious distortions, at least if we understand an ideal broadcasting market as one in which viewers receive what they want. From the standpoint of consumer sovereignty, the role of advertisers creates inarket failures. Of course broadcasters seek, other things being equal, to deliver more rather than fewer viewers because advertisers seek, other things being equal, more rather than fewer viewers. But advertisers have issues and agendas of their own, and the interests of advertisers can push broadcasters $\mathrm{m}$, or away from, directions that viewers, or substantial numbers of them, would like.

This is a substantial difference from the ordinary marketplace. Advertisers like certain demographic groups and dislike others, even when the numbers are equal; they pay extra amounts in order to attract groups that are likely to purchase the relevant products, and this affects programming

73. See C. Edwin Baker, Advertising ANd a Democratic Press 25-87 (1994). 
content. ${ }^{74}$ Advertisers do not want programming that draws product safety into question, particularly if it concerns their own products and sometimes even more generally. ${ }^{75}$ In addition, advertisers want programming that will put viewers in a receptive purchasing mood, and hence not be too "depressimg."76 Advertisers also tend to dislike programming that is highly controversial or that is too serious, and hence avoid sponsoring shows that take stands on public issues. ${ }^{77}$ In these ways, the fact that broadcasters are delivering viewers to advertisers - this is largely their charge, under existing arrangements-can produce offerings that diverge considerably from what would emerge if viewers were paymg directly for programming. To this extent the notion of consumer sovereignty is seriously compromised whenever programming decisions are a product of advertiser wishes.

\section{Informational Cascades and Broadcaster Homogeneity}

A second problem is that it is not clear whether broadcasters are now engaged, in anything like a systematic or scientific way, in catering to public tastes. At first glance it would seem obvious that broadcasters must be engaged in this endeavor (subject to the qualification just stated, involving the role of advertisers); if broadcasters are maximizing anything, they must be maximizing viewers (subject to the same qualification). In general, attracting viewers is their job. ${ }^{78}$ But there is reason to question this judgment, at least in its simplest form. Sornetimes rational people make decisions not on the basis of a full inspection of the alternatives, but on the basis of an understanding of what other people are doing. ${ }^{79}$ Because people obtain information from other people's actions, individual actions carry with them one or more "informational externalities," which potentially affect the decisions of others. Thus, rational and boundedly rational people, in business as elsewhere, rely on the signals provided by the words and deeds of others. ${ }^{80}$ This reliance can produce cascade effects, as $B$ follows $A$, and $C$ follows $B$ and $A$, and $D$, as a rational agent, follows the collected wisdom embodied in the actions of $A, B$, and $C$. Informational cascades often produce unfortunate outcomes, in fact outcomes far worse than those that would result if individuals accumulated information on their own. Sometimes, moreover, people use the "availability" heuristic, deeming an event more probable if an instance of its occurrence can be readily brought

74. See id. at 66-70.

75. See id. at $50-56$.

76. See id. at 62-66.

77. See id.

78. See generally ScHEchTER, supra note 50.

79. See Sushil Bikhchandani et al., Learning from the Behavior of Others: Conformity, Fads, and Informational Cascades, 12 J. EcoN. PerSP. 151, 164 (1998).

80. In a related vein, see Andrew Caplin \& John Leahy, Miracle on Sixth Avenue: Information Externalities and Search, 108 EcoN. J. 60 (1998). 
to mind. ${ }^{81}$ Using the availability heuristic, broadcasters might reason that if one show or another has attracted substantial viewers in the past, they should copy it. The result would be "fads" and "fashions" in programming. ${ }^{82}$

In theory, then, broadcasters might be building on the programming judgments of other broadcasters, often, perhaps, reacting to the "availability" of salient recent instances in which a particular program was especially popular (dealing, let us suppose, with the Clinton-Lewinsky scandal or the O.J. Simpson trial) or especially unpopular (dealing, let us suppose, with South Africa). If this is true, private decisions by broadcasters may produce both mistakes and homogeneity-mistakes, in the form of programming that is not what viewers want, and homogeneity, in the form of the "blind leading the blind."83

Recent evidence suggests that this theoretical account has considerable truth. A careful study shows that there is a good deal of simple imitation, as networks provide a certain kind of programining simply by imitating whatever other networks are doing. ${ }^{84}$ Recently popular shows tend to create cascade effects. This imitative behavior is not in the interest of viewers. On the contrary, it creates a kind of homogeneity and uniformity in the broadcasting market, and thus makes for problems in terms of providing what viewers "want." ${ }^{85}$ This is not a conventional market failure, but it suggests that existing decisions are unlikely to promote consumer sovereignty. The problem is rapidly diminishing with an increase in available programming options, but to the extent that substantial numbers of people continue to depend on a small number of broadcasters, the existence of informational cascades suggests that the market does not entirely promote consumer sovereignty.

\section{Externalities and Collective Action Problems}

Even if broadcasters did provide each viewer with what he or she wanted, a significant problem would remam, and from the economic point of view, this is probably the most serious of all. Information is a public good, and once one person knows something (about, for example, product hazards, asthma, official misconduct, poverty, welfare reform, or abuse of

81. See Timur Kuran \& Cass R. Sunstein, Availability Cascades and Risk Regulation, 51 STAN.

L. Rev. 683, 711-14 (1999).

82. See Bikhchandani et al., supra note 79 , at 161-62.

83. See David Hirshleifer, The Blind Leading the Blind: Social Influence, Fads, and Informational Cascades, in The New Economics of Human BeHavior 188 (Mariano Tommasi \& Kathryn Ierulli eds., 1995).

84. See Robert E. Kennedy, Strategy Fads and Competitive Convergence: An Empirical Test for Herd Behavior in Prime-Time Television Programming (1999) (Harvard Business School Working Paper 96-025, on file with the California Law Review).

85. See id. 
power), the benefits of that knowledge will probably accrue to others. ${ }^{86}$ Note in this regard Amartya Sen's remarkable observation that no famine has ever occurred in a democratic country with a free press. ${ }^{87}$ This observation is complemented by a series of less dramatic ones, showing the substantial benefits for individual citizens of a inedia that is willing and able to devote attention to public concerns, including the plight of the disadvantaged. ${ }^{88}$ Individual choices by individual viewers are highly likely to produce too little public interest programming in light of the fact that the benefits of viewing such programming are not fully "imternalized" by individual viewers. Thus, individually rational decisions may inflict costs on others at the same time that they fail to confer benefits on others. In this respect, the problem "is not that people choose unwisely as individuals, but that the collective consequences of their choices often turn out to be very different from what they desire or anticipate." $" 89$

Most generally, there are inultiple external effects in the broadcasting area; some of these are positive, but unlikely to be generated sufficiently by individual choices, while others are negative, and likely to be excessively produced by individual choices. Consider a decision to watch violent programming. ${ }^{90}$ In short, the effects of broadcasting depend on social interactions. Many of the resulting problems are connected with denocratic ideals. A culture in which each person sees a high degree of serious programming inay well lead to better political judgments; greater knowledge on the part of one person often leads to inore knowledge on the part of others with whoin she interacts. ${ }^{91}$ Perhaps inost important, a degree of serious attention to public issues can lead to improved governance through deterring abuses and encouraging governmental response to glaring problems. In these various ways, public interest programming can produce social benefits that will not be adequately captured by the individual choices of individual citizens; the same is true for programming that produces social costs, including apathy, fear, and increased criminal activity. ${ }^{92}$ Because of the collective action problem, an unregulated 1narket will underproduce public goods and overproduce public bads.

86. An illuminating and detailed discussion is Baker, supra note 71 , at 350-85.

87. See JeAN Dreze \& AMarTya Sen, India 76 (1995).

88. See id. at $75-76,173,191$.

89. Frank \& Cook, supra note 23, at 191; see also Pierre Bourdieu, ON Television 9-29 (Priscilla Parkhurst Ferguson, trans., The New Press 1998); Baker, supra note 71, at 350-85.

90. See HAMrLTON, supra note 45 , at 3-49 (discussing the market for violence).

91. See Baker, supra note 71, at 350-67.

92. See id. at 355-56; see also HAMmLON, supra note 45, at 20-30, 285-322. 


\section{B. Problems on Nonmarket Criteria: Children, Deliberative Democracy, and Related Issues}

Thus far the discussion has emphasized difficulties with television markets on conventional economic grounds; but it is wrong to endorse purely market approaches to television. ${ }^{93}$ Television is not best understood as an ordinary commodity, subject to the forces of supply and demand. There are several reasons why this is so. The unifying theme is that the American political tradition is committed to the ideal of deliberative democracy, ${ }^{94}$ an ideal that has animated much First Amendment doctrine and media regulation in general. ${ }^{95}$ Even if the media market were wellfunctioning from the economic point of view, there would be room for measures designed to promote a well-functioning system of democratic deliberation, especially in view of the importance of television to people's judgments about what issues are important and about what it is reasonable to think..$^{96}$ Consider, by way of general orientation, John Dewey's suggestion:

[W] hat is more significant is that counting of heads compels prior recourse to niethods of discussion, consultation and persuasion, while the essence of appeal to force is to cut short resort to such methods. Majority rule, just as majority rule, is as foolish as its critics charge it with being. But it never is merely najority rule. ... The important consideration is that opportunity be given that idea to spread and to become the possession of the multitude... The essential need, in other words, is the improvement of the methods and conditions of debate, discussion and persuasion. That is the problem of the public. ${ }^{97}$

\section{Children and the Hearing Impaired}

A well-functioning market may fail to serve certain categories of viewers. Of these the most obvious is children, who may be poorly served by an absence of educational programming ${ }^{98}$ or adversely affected by violent programming. ${ }^{99}$ It is reasonable to treat the resulting problems as "externalities," but the more natural conclusion is that the television market is creating difficulties even in the absence of a market failure. Because television has a significant role as an educational instrument, the failure to

93. Here, too, Baker has provided very illuminating discussions, and I draw on his account. See Baker, supra note 71 , at 355-65.

94. See Joseph M. Bessette, The Mrid Voice of Reason 6-39 (1994).

95. See MiNow \& LAMAY, supra note 50, at 15-65; SuNSTEIN, supra note 68, at 53-92.

96. See generally Shanto Iyengar, Is Anyone Responsible? How Television Frames Public Issues 127-44 (1991); Shanto Iyengar \& Donald R. Kindar, News That Matters (1987).

97. DEWEY, supra note 58, at 207-08.

98. See MrNow \& LAMAY, supra note 50, at 10-65.

99. See HAMILTON, supra note 45, at 76-128. 
serve children is a significant problem, ${ }^{100}$ for children lack much ability and much willingness to pay, and the result can be inadequate attention to their needs. ${ }^{101}$ To be sure, some children do have willingness to pay in the sense that they can pressure their parents to purchase certain programming and the products that support it. But it is implausible to say that market criteria exhaust the goals of a system of broadcasting with respect to the interests of children.

A well-functioning market may also disserve people who are hearing impaired, if they are deprived of access to television by the existing use of technology. This is a particular problem if they are unable to watch the news or to understand descriptions of emergency conditions. Here too there is potential room for a regnlatory response, partly in order to mclude the hearing impaired in civic activities by informing them of electoral issues and news in general. To be sure, some people who are hearing impaired are willing to pay for closed captioning. But such people face serious collective action problems in making their needs and wishes clear to advertisers and producers. In any case, there is an important democratic mterest im ensuring that certain programming is available to the hearing impaired, quite apart from their willingness to pay. There is thus strong reason to support commumications policies that promote the enfranchisement of people with disabilities.

\section{Balkanization}

Imagme that in a technological future, each person could devise her own preferred commumications "menu"; imagine, in other words, that programming could be fully, and not just partially, individuated. On economic grounds, this would seem to be a striking advance, a gnarantee of a kind of optimality, a victory for both freedom and welfare. But from the democratic standpoint, it is the stuff of science fiction, and it contains serious risks, above all because it may well result im a situation im which many or most are not exposed to diverse views, but imstead hear louder and louder echoes of their own preexisting convictions. ${ }^{102}$ One of the advantages of a well-functioning system of freedom of expression is that it supplies one or more genuinely public spheres, in which diverse points of view are presented and confront one another, and are exposed to people who have a willingness to learn. General-imterest newspapers and magazmes often do precisely this, and it is important to make provision for multiple forums of

100. See MiNow \& LAMAY, supra note 50, at 100-26.

101. See id.; see also Price, supra note 9, at 192, 246.

102. See Shap1Ro, supra note 2 , at $105-32$. See also the discussion of group polarization in Schkade et al., supra note 62; Sunstein, supra note 62. 
this kind. Insofar as they disregard this point, market conceptions of commumications miss a central matter. ${ }^{103}$

\section{Citizens, Consumers, and Precommitment Strategies}

The most important point is that a market system may fail to provide a system of communication that is well-adapted to a democratic social order. People are quite aware of this fact, whatever they may choose in their capacity as viewers and listeners; and they may, and often do, seek collective corrections. The problem with the economic approach is that it makes private preferences normative, or decisive, for purposes of policy.

In short, there is a pervasive difference between what people want in their capacity as viewers (or "consumers of broadcasting") and what they want in their capacity as citizens. ${ }^{104}$ Both preferences and values are a function of the setting in which people find themselves; they are emphatically a product of social role..$^{105}$ In these circumstances, it would be wrong to think that the choices of individual viewers are definitive, or definitional, with respect to the question of what individuals really prefer. On the contrary, a democratic public, engaged in deliberation about the world of telecommunications, may legitimately seek regulations embodying aspirations that diverge from their consumption choices.

Participants in politics may be attempting to promote their metapreferences, or their preferences about their own preferences. They may be attempting to carry out a precommitment strategy of some kind. They may be more altruistic or other-regarding in their capacity as citizens, perhaps because of the nature of the goods mvolved. They may be more optimistic about the prospects for change when acting collectively, and therefore able to solve a collective action problem faced in their individual capacities. ${ }^{106}$ In this last respect, the democratic argument for departing from private consumption choices converges with the argument emphasizing the character of information as a public good.

When participants in a democracy attempt to make things better and do not smiply track their consumption choices, it is not helpful to disparage

103. See LESSIG, supra note 66, at 185-86. See also JÜRGEN HABERMAS, BETWEen FACTS AND NoRMs 362 (1996), emphasizing that

[t] he diffusion of information and points of view via effective broadcasting media is not the only thing that matters in public processes of commuuication, nor it is the most important.... [T] for structuring public opinion. Agreement on issues and contributions develops only as the result of more or less exhaustive controversy in which proposals, information, and reasons can be more or less rationally dealt with.

104. A good discussion is Daphna Lewinsohn-Zamir, Consumer Preferences, Citizen Preferences, and the Provision of Public Goods, 108 YALE L.J. 377 (1998).

105. See generally Cass R. Sunstein, Social Norms and Social Roles, 96 Colum. L. Rev. 903, 906-17 (1996).

106. The latter two points are emphasized in id. at 944-46; in the particular context of broadcasting, see Baker, supra note 71, at 401-04. 
their efforts as "paternalism" or as "meddling." Their efforts at reform represent democracy in action. ${ }^{107}$ It is entirely appropriate for government to respond to people's aspirations and commitments as expressed in the public realm. This is especially so when a democratic polity is itself attempting to ensure more in the way of democratic deliberation.

\section{Endogenous Preferences}

On the market view, freedoin consists in the satisfaction of viewer preferences, whatever their content. But this is an inadequate conception of freedom. ${ }^{103}$ It is important to ensure a degree of freedom in the formation of preferences, and not only in preference satisfaction. If people's preferences are formed as a result of the existing arrangement, including limitations in available opportunities, or of exposure to a limited kind of television, then it makes no sense to say that the existing arrangement can be justified by reference to their preferences.

It seems clear that the public's "tastes," with respect to television programming, do not coine from nature or from the sky. They are partly a product of current and recent practices by broadcasters and other programmers. They are often generated by the market. ${ }^{109}$ What people want, im short, is partly a product of what they are accustomed to seeing. It is also a product of existing social norms, which can change over time, and which are themselves responsive to existing commercial fare. Tastes are formed, not just served, by broadcasters.

This point raises doubts about the idea that government policy should simply take viewers' tastes as given. In an era in which broadcasters are providing a good deal of public interest programming, dealing with serious issues in a serious way, many inembers of the public will cultivate a taste for that kind of programming. This effect would promote democratic ideals by disseminating information and helping to increase deliberation. ${ }^{110}$ In an era in which broadcasters are carrying sensationalistic or violent material, members of the public inay well cultivate a taste for nore of the same. "Free marketeers have little to cheer about if all they can claim is that the inarket is efficient at filling desires that the inarket itself creates. . . Just as culture affects preferences, so also do markets influence culture." "II If this is so, the ideal of consumer sovereignty is placed under some pressure; market activities cannot easily be justified by reference to tastes that they themselves generate.

107. See Baker, supra note 71, at 401-11.

108. See generally JoSEPH RAZ, THE MORALITY OF FREEDOM 369-78 (1986) (discussing social preconditions for autonomy); AMartya SEn, Commodities and CaPabilities (1985).

109. See Baker, supra note 71, at 404-10.

110. For evidence that the effects of television on this count are far from fanciful, see IYENGAR, supra note 96 , at 26-116.

111. FRANK \& COOK, supra note 23, at 201. 
This point should not be overstated. Probably broadcasters have limited power to push tastes very dramatically in one direction or another. But at a minimum, the idea that viewers' tastes are endogenous to existing fare should be taken as a cautionary note about treating consumption choices as decisive for purposes of policy. There is nothing illegitimate about policies that depart from consumption choices in favor of widely held social aspirations. But there is reason for broader concern about the adverse effects of certain kinds of programming-including a failure to cover serious issues in a serious way $\longrightarrow$ on democratic judgments. ${ }^{112}$

\section{Paternalism? Elitism?}

It might be tempting to respond that the arguments thus far are unacceptably paternalistic, indeed elitist. If individual listeners and viewers prefer fare of a certain kind, how can there be any groun'd for legitimate complaint? Perhaps children pose a special case, but even here parental guidance is far from unusual. Why should government displace the choices of adults, includimg parents, and substitute choices of its own?

Let us take the charge of paternalism first. Notice that insofar as the argument stresses a collective action problem faced by individual consumers, paternalism is not at work at all. Notice too that insofar as the argument centers on people's desires in their capacity as citizens, no paternalism is involved; the claim is that (a majority of) the people seek to push consumption patterns in certain directions. This form of precommitment strategy, or autopaternalism, should not be confused with paternalism of any objectionable kind. ${ }^{113}$ To be sure, this argument depends on an empirical proposition to the effect that in their capacity as citizens, people would like a communications market of a certain kind. ${ }^{114}$ But the proposition seems at the very least highly plausible.

To the extent that I have emphasized the endogeneity of preferences, my argument might seem to verge on objectionable paternalism. Certainly preferences are not being taken as given. But there is nothing objectionable about insisting that in a democracy, free and equal citizens are entitled to a public culture that will promote their freedom and their equality. It is one thing to say that a government should not be authorized to overcome people's judgments, when those people are armed with adequate information. It is quite another to say that government should be permitted to take modest, viewpoint-neutral steps to promote the operation of a democratic order by, for example, ensuring free air time for candidates, or subsidizing

112. See IYENGAR, supra note 96, at 46-68 (discussing television news' framing of poverty, unemployment, and racial inequality).

113. See Jon ElSTER, Ulysses and the Sirens 36-47 (1979) (discussing precommitment strategies).

114. Of course some such judgments would run afoul of the First Amendment-if, for example, they involved a form of viewpoint discrimination. 
certain kinds of fare, or promoting substantive discussion of substantive questions. And the charge, indeed the very notion, of paternalism becomes harder to understand when the preferences involved are a product of the very system whose legitimacy is at issue.

Nor is there anything unacceptably "elitist" about a commumications policy that fosters education of children, and more substantive and diverse coverage of civic issues. To the extent that substantive programming is said to have special appeal for "elites" (a vague and empirically uncertain claim), the problem lies not im a policy that encourages such programming, but in unjust background conditions, and in particular, in unjust inequalities in education. A communications policy that attempts to promote more discussion and understanding of public issues is a partial way of overcommg those unjust inequalities. It is not a way of catering to them.

To be sure, the charge of elitism would have force if programming content were dictated by a political elite, promoting its own preferred fare free from effective electoral control. It is crucial to the argument offered here that regulatory strategies-froin the FCC or from Congress-are subject to democratic supervision. It is also crucial that any effort to promote programming of a certain kind is defended, not by the preferences of the regulators, but by democratic values that should, at least in principle, meet with widespread public approval. The judgment on behalf of deliberative democracy (and corresponding regulatory strategies) does not itself come from the sky. Any view on its behalf depends, not on a claim that it is extracultural, but on the arguments that are made on its behalf.

There is no argument here for any particular conception of public interest broadcasting. A talk-show on racial violence may well be at least as desirable, for democratic purposes, as a public debate between candidates for public office. Staged and self-serving statements by politicians on C-Span may not add more, and may add less, to public understanding than (easily imaginable) rock or rap music videos. The point of a system of public service broadcasting would be to encourage those who produce television programming to use their own creativity to promote deliberation about public issues, not to force programming into any particular mode.

Of course public interest programming will do little good if people simply change the channel. No one urges that the government should require people to watch governmentally preferred programming. The only suggestion is that if the government, responsive as it is to citizen aspirations, seeks to ensure more public interest programming than the market does, there is no principled ground for complaint. In any case it is likely that some people would watch the resulting programming and develop a taste for it; that empirical probability is all that is necessary to vindicate the suggestions inade here. 


\section{Constitutional Notes}

This is not an Article about the First Amendment or about constitutional law; but it will be useful to conclude this Section with some brief notations on those subjects. From what has been said thus far, it should be clear that a central purpose of the First Amendment is to ensure a wellfunctioning democratic order. ${ }^{115} \mathrm{~A}$ system of free expression is designed in large part to protect the preconditions for a form of sovereignty that is suited to genuine self-governance. It is not designed to protect whatever happens to come out of the mouths, or pens, or word-processors of those who are attempting to speak. This view receives support on both historical and philosophical grounds. ${ }^{116}$

One implication is that government may well be permitted to regulate speakers who are not contributing to dernocratic deliberation-for example, those who advertise cigarettes. Another implication is that government efforts to promote a well-functioning democratic order should not be invalidated even if they involve content regulation, so long as there is no discrimination against any point of view. If government seeks to ensure a certain level of educational programming, or if it allows free air time for candidates, or if it provides a right of access for those who attempt to speak on political issues, it is not violating the free speech guarantee merely by virtue of the fact that it is intruding on the discretion of those who own stations. A conclusion to the contrary would convert the First Amendment into a form of Herbert Spencer's Social Statics, ${ }^{117}$ or at least Richard Epstein's Simple Rules for A Complex World, ${ }^{118}$ it would tear the First Amendment from its theoretical underpinnings. ${ }^{119}$

On this view of the First Amendment, there is no tension between constitutionalism and democracy, or between individual rights and majority rule, properly understood; robust rights of free expression are a precondition for both democracy and majority rule, properly understood. In this way, private autonomy is in no tension with, but is on the contrary inextricably intertwined with, the notion of popular sovereignty. ${ }^{120}$ The point is not limited to freedom of speech. Protection of private property, for example, can be seen as a precondition of the status of citizenship; those whose holdings depend on the beneficent exercise of government

115. See AleXANder Meiklejohn, FreE Speech and Its Relation to Self-Government (1948); SUNSTEIN, supra note 68, at 121-66.

116. See generally HABERMAS, supra note 18, at 283-328 (discussing theory of deliberative democracy); SUNSTEIN, supra note 68, at 241-50 (same).

117. Herbert SPENCER, SOCIAL Statics (1913).

118. EPSTEN, supra note 8 (arguing for six simple rules of governance).

119. None of this means that the First Amendment is only about democratic self-government. It has other purposes as well. See generally SUNSTEIN, supra note 68, at 137-48.

120. See Jürgen Habermas, The Inclusion of THe Other 258-60 (Ciaran Cronin \& Pablo De Greiff eds., 1998). 
discretion are hardly in a position to operate as independent citizens in the public domain. And the protection against unreasonable searches and seizures, and other abuses of authority by the police, are safeguards of individual liberty that simultaneously prevent attacks on popular sovereignty. The account offered here thus provides a basis for understanding many mdividual rights in a way that fuses the "freedoin of the ancients" and the "freedo1n of the moderns."

\section{III \\ PRinciple, Policy, TeChNology}

These points suggest that there is good reason, in principle, for some kind of regulatory response to existing markets in television. But nothing said thus far argues for any particular governmental initiative. There is no simple "match" between the identifiable market and nonmarket failures and public interest requirenents in general. For example, it is hard to imagine a legitimate governmental response to the problein of excessive homogeneity on the major networks. We have also seen that existing public interest obligations are extremely varied; each of thein must be assessed on its own.

At first glance, policies that attempt to promote better programming for children are inost securely supported by the arguments made thus far (as a response to what is reasonably classified as a narket failure, and also as a way of increasing positive externalities and of promoting social aspirations). Efforts to ensure that hearing impaired people are able to enjoy television, through closed captioning, are justifiable on similar grounds. There is rooin also for efforts to ensure better coverage of electoral campaigns-perhaps through a requirement of free air time for candidates, perhaps through a private "code" designed to ensure more substantive discussion. Disclosure requirements, allowing the public to have a general sense of broadcaster performance, seem to be justified as a nonintrusive inethod for allowing civic aspirations to help influence future programming. As a response to the possibly unfortunate effects of advertiser pressures, and also as a way of ensuring against a destructive "race to the bottoin" with respect to programming content, a general code of broadcaster behavior seenis appealing. ${ }^{122}$

\section{A. Practice}

There are important pragmatic questions here. To say that a response is justified in principle is not at all to say that it will succeed $\mathrm{m}$ practice. Just as in the environinental area, where command-and-control regulation

121. Id. at 258.

122. See discussion infra Part VI. 
has produced unintended adverse consequences, ${ }^{123}$ many problems have emerged with command-and-control regulation of the kind that has typified FCC regulation for most of its history. Consider, for example, the fairness doctrine, designed to ensure exposure to public issues and to allow diverse voices to have access to the airwaves. A serious problem with the fairness doctrine is that it appears to have discouraged stations from covering controversial issues at all, thus ensuring a kind of bland uniformity that disserves democratic goals. ${ }^{124} \mathrm{~A}$ uniform set of mandates may also produce waste and poor programming; if a network is especially bad at generating good shows for children and has a hard time attracting a children's audience, is it so clear that that network should be faced with the same obligations as everyone else? In view of the great diversity of the broadcasting market, a "one-size-fits-all" approach may be far more costly, and less effective, than creative alternatives.

It is useful to distingnish here between approaches that suppress markets and approaches that supplement markets. ${ }^{125}$ Market-suppressing approaches include minimuin wage and inaximuin hour laws, or price and wage controls. Market-supplementing approaches mclude job-training programs and the earned mcome tax credit. In telecommunications policy, the fairness doctrine was a market-suppressing reinedy; so too are requirements that broadcasters provide three hours of educational programming per week, or a certain amount of time for candidates for public office. By contrast, the grant of public funds to the Public Broadcasting System (PBS) is a market-supplementing approach; so too is a subsidy granted to each of the networks, designed to ensure a certain amount of public interest programming. To be sure, the line between the two approaches can be thin when the market-suppleinenting approach ends up displacing material that would otherwise be supplied in accordance with forces of supply and demand.

\section{B. Communications Past, Present, and Future: Planned Obsolescence and Beyond}

The arguments offered thus far have not specifically addressed the new market in communications. An especially important question is whether emerging changes in television technology should strengthen satisfaction with market outcoines.

123. See Cass R. Sunstein, Free Markets and Social Justice 245-283 (1997).

124. See Thomas W. Hazlett \& David W. Sosa, Was the Fairness Doctrine a "Chilling Effect"? Evidence from the Postderegulation Radio Market, 26 J. LEGAL STuD. 279 (1997) (offering an affirmative answer to the question in the title).

125. See DREZE \& SEN, supra note 87, at 21-24 (discussing market supplementing strategies). 


\section{Predicting the Future}

Of course the most striking feature of the emerging commumications market is a dramatic increase in the number of available stations and programming options. The existing regulatory regime was designed for a systein with three private broadcasting networks and PBS. In 1996, about thirty-five percent of people who had television remained dependent on broadcasters, which results in access to five or six stations. ${ }^{126}$ This means that about two-thirds of viewers had access to between fifty and one hundred stations, including the all-news stations C-SPAN and CNN, and a range of "soft news" stations such as MSNBC. By itself this is an extreinely significant change, and the shift from this situation to one in which most people have access to (say) 500 stations inay be only one of degree.

More dramatic innovations are coming in the future, with the possible ultimate "convergence" of various television sources, including digital television and the Internet. ${ }^{127}$ If a "television set" becomes akin to a coinputer monitor that provides access to the full range of American inagazines, would not the case for public interest regulation be substantially weakened? The foregoing discussion offers an ambivalent answer. Soine of the probleins with the niarket status quo would dissipate, but others would reniain. Let us explore these questions in more detail.

For purposes of analysis, we might separate the inarket for television into four rough stages. The first is the period between the 1940 s and 1970 s - the inarket for which the existing regulatory system was designed; call this the old regmie. As noted, the old regime included three large networks and also PBS; the four stations provided all of what Americans knew as television. The second market is one of the 1990s; call this the transitional state. Here the most dramatic change is in the number of available options. This is a system in which a substantial percentage (about thirty-five percent) of the viewing public relies on five broadcasters and PBS, but in which sixty-five percent of the public has access to cable television, and thus is able to choose among fifty or more options. ${ }^{128}$ Of that sixty-five percent, a growing segment is able to see well over one hundred stations. But in the transitional state, broadcasters. continue to have a special role, both because a substantial number of people do not have access to cable at all, and because even cable viewers watch the inajor networks disproportionately.

The third stage, likely to begin shortly, is continuous with the transitional state; call this the stage of multiple options. This will be a market in which broadcasters will continue to be seen by more people than other

126. See U.S. BUREAU OF THE CENSUS, supra note 65 .

127. See OWEN, supra note 3, at 327-33.

128. See U.S. BUREAU OF THE CENSUS, supra note 65. 
providers, but they will become decreasingly distinctive in terms of both the size and the nature of their audience. Even more people will have access to cable or other options, and many of those who rely on broadcasting will be able to have more options too. But broadcasters will continue to be seen by a disproportionate number of people, if only because a shrinking but still substantial percentage of viewers will continue to have access only to broadcasters; this significant subgroup is important partly because of its sheer size and partly because it includes an especially high percentage of people, including children, who are poor and poorly educated. In this stage, broadcasters will in some ways be akin to Newsweek, Time, and U.S. News \& World Report, in the sense that they will have a relatively dominant role in terms of sheer numbers. But they will have to compete with other programmers, some general, soine specialized, with analogues (1nost of them now in place on cable or even the Internet) to Sports Illustrated, The Economist, Dog Fancy, National Review, National Geographic, The New Republic, Consumer Reports, Playboy, and many more. This third stage will be marked by the rise of digital television, which is allowing broadcasters to "inultiplex," that is, to provide two, three, four, or even five programs where they could previously provide only one. The result may be to make broadcasters themselves more specialized. ${ }^{129}$ It is hard to speculate about the future, but the best prediction is that a situation of this kind will prevail for the next decade and more.

The final stage-call it one of technological convergence-is one of substantial or possibly even complete shrinkage in the distinctive role of broadcasters. ${ }^{130}$ This will be a stage in which television programming can be provided via the Internet, over telephone lines, or both; a television, or one kind of television, inay itself be a simple computer monitor, connected to various programming sources from which viewers niay make selections. If it is economically feasible for broadcasters to continue as such, they are unlikely to have a special role and will be among a large number of providers. At most, and extending the analogy to Time or Newsweek, they will have a soniewhat larger and more general audience than most of their competitors; perhaps they will be entertainnent conglomerates with multiple stations and programs. Perhaps they will not be distinctive at all..$^{131}$ The most extreme version of this final stage would be akin to the market for books, in which people make individual choices, usually not filtered by an nitermediary offering packages. ${ }^{132}$

\footnotetext{
129. See id. at 100 .

130. This shrinkage may or may not occur as a result of convergence. For discussion, see $i d$. at 329.

131. This speculation is questioned in OWEN, supra note 3, at 328-33, and Goldberg et al., supra note 5 , at 296 .

132. I put to one side the complexities introduced by Amazon.com and various book clnbs.
} 


\section{Regulatory Options and Technological Change}

All of the arguments offered thus far-about market and nonmarket failures-make sense for the old regime and the transitional state. They also seem to make sense for the emerging third stage of multiple options; recall that even here, a substantial segment of the public will depend on broadcasters only, and people with access to cable and other alternatives continue, statistically speaking, to watch a disproportionate amount of broadcast fare. But arguments for public interest obligations would be less sensible as applied to a market in which broadcasters occupy no special role, partly because some of the relevant problems would be diminished, partly because in such a market it seems peculiar to impose on broadcasters, and no one else, a special duty to protect public interest goals. In that inarket, perhaps every station should be faced with soine of the requirements discussed below (in particular, the disclosure requirement). But the case for other requirements (snch as uniform mandates, a broadcaster-only code, or "play or pay") would be greatly weakened, not least since it wonld seein arbitrary to simgle out broadcasters for such requirements.

Let us examine, in inore detail, the force of the particular arguinents as the market changes over time. Even if informational influences produce a degree of homogeneity among broadcasters, and even if broadcasters tend to follow one another, the increasing number of channels means that for inost Americans, there is far more heterogeneity now than there was a decade ago, and a great deal more heterogeneity is likely in the near future, probably dramatically increasing heterogeneity. At the same time, advertisers are likely to have an increasingly weak role in determining overall programming content. When a few broadcasters exhaust the market, advertiser preferences could have a nore substantial effect than they now do. Thus, two of the arguments made above-involving the market failures resulting from advertiser pressures and informational cascades-are significantly weakened. ${ }^{133}$

But some of the argunents offered above-especially those focused on deinocratic ideals-retain considerable force. Even in the very long tern, there will continue to be substantial external benefits from public interest programming, benefits that are not adequately captured by individual viewer choices. And to the extent that citizens seek to push communications policy toward (for example) inore and better programming for children, or free air time for candidates, or greater access for the hearing inpaired, changes in the evolving market offer only partial answers. Heterogeneity may be an inadequate solution here. It

133. Of course these changes should not be overstated. Recall that 32 percent of American households with televisions still lack cable television, and that a substantial number of Americans are likely to depend on over-the-air programming for the not-too-distant future; hence, the increasing heterogeneity is not quite as dramatic as it might seem. 
is reasonable for citizens to believe that there should be very general public exposure to public issues, and that it is not sufficient to have one, or two, or three, or even more stations (CNN, C-SPAN, MSNBC) that take such issues seriously. Indeed, citizens may favor a kind of general precommitment strategy - operating against their own particular viewing choicesthrough which broadcasters, at least, are required to devote some time to educational or civic programming. Thus, the presence of news-only stations, especially on cable, is not a sufficient response to those who want broadcasters to do more and better. It is insufficient partly because a significant segment of the population will have no access to cable at all, and partly because in their capacity as citizens, people inay favor a precommitment strategy that favors certain public interest goals.

In the very long run, this argument too will be weakened. As we have seen, the strongest objection would come when broadcasters are no longer genuinely distinctive; when this is the case, it will seem arbitrary to encourage broadcasters, but not others, to provide certain kinds of programming. In the face of such changes, it will indeed make sense to adapt the proposals discussed below to this dramatically altered market. But it is hard to explore this question in the abstract; everything turns on the particular regulatory proposal that is at issue.

The question of adaptation will arise at several points below. For now let us observe only that in the extreme situation-when broadcasters are not in any sense distimctive-the case for regulation limited to broadcasting would be very weak, and alternative strategies, involving funding of public interest programming, would be better. Thus, iny emphasis here-on disclosure, economic incentives, and voluntary self-regulation-is designed for a (likely not inconsiderable) period in which broadcasters continue to occupy a special role. To simplify a coinplex story, the very long-term may call for a combination of public subsidies for high-quality programming and disclosure requirements for general-interest stations. But in the shorter term, there is a great deal more to consider. And it is important to see that in the long-term inuch may be lost, as well as gained, with a highly balkanized communications systein in which inany people are not exposed to serious programming, many others simply hear echoes of their own voices, and widely shared viewing experiences becoine rarer. ${ }^{134}$

There is a large issue in the background here: how to define the market froin which to assess proposals for public interest requireinents. Traditionally, "television broadcasting" has been viewed as the relevant category, but skeptics might well ask why the real category is not "sources of information and entertainment." If that category were the relevant one, there might seein to be no problem calling for requirements at all-not in the 1930s, not in the 1950s, not in the 1970s, not in the 1990s, and not in

134. See Lessig, supra note 66 , at $\mathbf{1 8 5 - 8 6 .}$ 
the foreseeable future. The traditional approach seems best defended on the ground that television has a special role and salience; if this is no longer true, a particular regulatory regime, limited to television, loses its rationale. ${ }^{135}$ The best argument for the future is that even if television as a whole is far from the only source of information and entertainment, it continues to have a distinctive social role, and efforts to promote the goals associated with public imterest programming might do considerable good.

\section{IV}

\section{DisCLOSURE}

Consider a simple proposal: broadcasters should be required to disclose, in some detail and on a quarterly basis, all of their public service and public interest activities. The disclosure might include an accounting of any free air time provided to candidates, educational programming, charitable activities, programming designed for traditionally under-served communities, closed captioning for the hearing impaired, local programming, and public service announcenents. ${ }^{136}$ The hope, vindicated by experience with similar approaches in environmental law, ${ }^{137}$ is that a disclosure requirement will by itself trigger improved performance, by creating a kind of competition to do better, and by enlisting various social pressures in the direction of inproved performance. A requirement of this sort would be part of a general trend in federal regulation, one with considerable proinise. $^{138}$

\section{A. Precursors}

Many statutes and regulations now require the disclosure of information. Some of these are designed to assist consumers in making informed choices; such statutes are meant to be market-enhancing. By contrast, others are designed to trigger political rather than market safeguards; such statutes are meant to enhance democratic processes. The most famous of these is the National Environmental Policy Act (NEPA). ${ }^{139}$ Enacted in 1972, the principal goal of NEPA is to require the government to compile and disclose environmentally-related information before the government goes forward with any projects having a major effect on the

135. But see BoLlinger, supra note 7, defending two competing regulatory regimes, one for television and one for the print media.

136. See FINAL REPORT, supra note 19, at 104-05, for an illustration.

137. See Madhu Khanna et al., Toxics Release Information: A Policy Tool for Environmental Protection, 36 J. Envtl. Econ. \& MGMT. 243 (1998).

138. See Wesley A. Magat \& W. Kip Viscusi, Informational Approaches to Regulation (1992) (discussing possible effectiveness of disclosure); Sunstein, supra note 24, at 618-29 (discussing this trend).

139. 42 U.S.C. $\$ \$ 4321-4370$ (1994). 
environment. ${ }^{140}$ NEPA does not require the government to give environmental effects any particular weight, nor is there judicial review of the substance of agency decisions. ${ }^{141}$ The purpose of disclosure is principally to trigger political safeguards, coming from the government's own judgments or from external pressure. Governmental imdifference to adverse environmental effects is perfectly acceptable under NEPA: the idea behind the statute is that if the public is not indifferent, the government will have to give some weight to environmental effects.

Probably the most successful experiment in information disclosure is the Emergency Planning and Cominunity Right-to-Know Act (EPCRA). ${ }^{142}$ Under this statute, firms and individuals must report to state and local government the quantities of potentially hazardous chemicals that have been stored or released into the environment. ${ }^{143}$ On the basis of the relevant results, the EPA publishes pollution data about the releases of over 300 chemicals from over 20,000 facilities. ${ }^{144}$ This has been an exceptional success story, one that has well exceeded expectations at the time of enactinent. ${ }^{145}$ A detailed report suggests that EPCRA has had important beneficial effects, spurring innovative, cost-effective programs from the EPA and from state and local governnent. ${ }^{146}$

Many other statutes nivolving health, safety, and the environment fall into the category of information disclosure nieasures. The Animal Welfare $\mathrm{Act}^{147}$ is designed partly to ensure publicity about the treatment of animals; thus covered research facilities and dealers are required to file reports with the government about their conduct, with the apparent goal that the reports will deter noncompliance and also allow continuing monitoring. ${ }^{148}$ In addition to its various command-and-control provisions, the Clean Air Act $^{149}$ requires companies to create and disclose "risk management plans" mvolving accidental releases of cheimicals; the plans must include a worstcase scenario. ${ }^{150}$ The Safe Drinking Water Act ${ }^{151}$ was aniended in 1996 to

140. See Calvert Cliffs' Coordinating Comm., Inc. v. United States Atomic Energy Comm'n, 449 F.2d 1109 (D.C. Cir. 1971).

141. See Strycker's Bay Neighborhood Council, Inc. v. Karlen, 444 U.S. 223, 227-28 (1980).

142. 42 U.S.C. $\$ \S 11001-11050$ (1994).

143. See id. $\$ 11023$.

144. See HAMilTon, supra note 45 , at 302.

145. See Robert V. Percival et al., Environmental Regulation: Law, Science, and POLICY 612-16 (2d ed. 1996) (discussing informational approaches); James T. Hamilton, Exercising Property Rights to Pollute: Do Cancer Risks and Politics Affect Plant Emission Reductions, $18 \mathrm{~J}$. Rusk \& UNCERTAINTY 105, 106-08 (1999) (discussing success of toxic release inventory); Khanna et al., supra note 137, at 243 (discussing success of toxic release inventory and stockholder responses to release of relevant information).

146. See U.S. General Accounting Office, Toxic Chemicals (1991) (report to Congress).

147. 7 U.S.C. $\$ \$ 2131-2159$ (1994).

148. See id. $\$ \S 2140,2142$.

149. 42 U.S.C. $\$ \$ 7401-7671$ (1994).

150. Id. $\$ 7412(r)$. 
require annual "consumer confidence reports" to be developed and disseminated by community water suppliers. ${ }^{152}$ Statutes governing discrimination and medical care also seem committed partly to the idea that "sunlight is the best of disinfectants"; 153 thus they require covered institutions to compile reports about their conduct and compliance with applicable law. The Federal Election Campaign Act $^{154}$ requires political committees to disclose a great deal of information about their activities.

Of course there is an overlap between informational regulation designed to assist consumers and informational regulation designed to trigger political checks. A statute that requires companies to place "eco-labels" on their products may produce little im the way of consumer response, but shareholders and participants in the democratic process may attempt to sanction those companies whose labels reveal environmentally destructive behavior. Companies will know this in advance, with likely behavioral consequences. The risk of sanctions from shareholders and state legislatures may well produce environmental improvement even without regulation.

A great deal of recent attention has been given to informational regulation in the particular context of the communications industry. As an alternative to direct regulation, which raises especially severe First Amendment problems, the government might attempt to increase information instead. Thus, the mandatory "v-chip" is intended to permit parents to block programming that they want to exclude from their homes; the v-chip is supposed to work hand-m-hand with a ratings systen. ${ }^{155}$ Similarly, a provision of the 1996 Telecommunications Act requires television manufacturers to include technology capable of reading a program rating inechanism; requires the FCC to create a ratings nethodology if the industry does not produce an acceptable ratings plan within a year; and requires that broadcasters include a rating in their signals if the relevant prograni is rated. ${ }^{156}$ Spurred by this statute, the networks have generated a systen for television ratings, which is now in place. ${ }^{157}$ The question is whether disclosure requirements might be enlisted more generally.

\section{B. Rationale}

Why has information disclosure beconie such a popular regulatory tool? There are several answers. For various reasons, a nrarket failure inay

151. 42 U.S.C. $\$ 300 \mathrm{~g}(1994)$.

152. 42 U.S.C. § $300 \mathrm{~g}-3$ (c)(4) (Supp. II 1996).

153. The phrase comes from Louts D. BRANDE1s, OTHER PEOPLE's MONEY 92 (1914).

154. 2 U.S.C. § $441 \mathrm{a}-411 \mathrm{~h}$ (1994).

155. See HAMmTON, supra note 45 , at 289-92.

156. See Telecommurications Act of 1996, Pub. L. No. 104-104, § 551, 110 Stat. 56; see also

HAMILTON, supra note 45 , at 302 .

157. See $\S 551,110$ Stat. at $141-42$. 
come in the form of an inadequate supply of information. ${ }^{158}$ Because information is generally ${ }^{159}$ a public good-something that if provided to one is also provided to all or many - workers and consumers may attempt to free ride on the efforts of others, with the result that too little information is provided. For this reason, compulsory disclosure of information can provide the simplest and most direct response to the relevant market failure.

Information disclosure is often a far less expensive and more efficient strategy than command-and-control, which consists of rigid mandates about regulatory ends (a certain percentage reduction in sulfur dioxide emissions, for example), regulatory means (a technological mandate, for example, for cars), or both. ${ }^{160}$ A chief advantage of informational regulation is its comparative flexibility. If consumers are informed of the salt and sugar content of foods, they can proceed as they wish, trading off various product characteristics however they see fit. If workers are given information about the risks posed by their workplace, they can trade safety agamst other possible variables (such as salary, investments for children or retirement, and leisure). ${ }^{161}$ If viewers know the content of television programs in advance, they can use market methods (by refusing to watch) or political methods (by complaining to stations) to induce changes. From the standpoint of efficiency, information remedies can be better than either command-and-control regulation or reliance on markets alone.

From the democratic poimt of view, informational regulation also has substantial advantages. A well-functioning system of deliberative democracy requires a certain degree of information so that citizens can engage in their monitoring and deliberative tasks. Subject as they are to parochial pressures, segments of the government may have insufficient imcentives to disclose information on their own; consider the Freedom of Information Act (FOIA) ${ }^{162}$ or the Federal Election Campaign Act (FECA), ${ }^{163}$ designed to counteract the self-interest of government or private groups, which may press in the direction of too little disclosure. A good way to enable citizens to oversee private or public action, and also to assess the need for less, more, or different regulation, is to inform them of both private and public

158. See ANThony Ogus, Regulation: Legal Form ANd ECONOMTC THEORY 121-25 (1994).

159. Of course it is possible to give information more "private good" characteristics, and innovative approaches can be expected in the next decade. Consider, for example, fees for access to information on the Internet, or the subscription-based Consumer Reports; neither of these approaches converts information into a private good, but both reduce the range of people who may, without high cost, have access to it. It is possible to imagine a range of approaches that would diminish the cost of access for some while increasing it, or holding it constant, for others.

160. See OGus, supra note 158, at 121-49.

161. See SUNSTEIN, supra note 123, at 329-30.

162. 5 U.S.C. $\$ 552$ (1994).

163. 2 U.S.C. $\$ 441 \mathrm{a}-441 \mathrm{~h}(1994)$. 
activity. The very fact that the public will be in a position to engage in general monitoring may well be a spur to desirable outcomes.

EPCRA is the most obvious example here. Sharp, cost-effective, and largely unanticipated reductions in toxic releases have come about without anything in the way of direct regulation. ${ }^{164}$ One of the causes appears to be adverse effects on stock prices fron1 repeated disclosure of high levels of toxic releases. ${ }^{165}$ In the area of broadcasting, it is possible to hope that disclosure of public interest programming, and the mere need to compile the information each year, can increase educational and public affairs programming without imvolving government mandates at all. A primary virtue of informational regulation is that it triggers political safeguards and allows citizens a continuing oversight role, one that is, in the best cases, largely self-enforcing.

None of this is to say that infornational regulation is always effective or desirable. Under imaginable assumptions, such regulation would be much less effective than command-and-control regulation and much more expensive than reliance on markets unaccompanied by disclosure requirements. Sometimes informational strategies cost more than they are worth, and inay be ineffectual or even counterproductive. Whether these are convincing objections depends on the incentives faced by those who disclose, and these incentives are likely to differ with context. Undoubtedly, the most successful cases of disclosure involve well-organized groups able to impose reputational and financial harm on those engaged in harmful activity. ${ }^{166}$

\section{The Minimal Proposal}

We are now in a position to discuss a disclosure requirement for public interest programming in somewhat more detail. On a quarterly basis, every broadcaster should be required to make public the full range of public interest and public service activities in which it has engaged. The relevant activities might involve free air time for candidates, educational programming, public service announcements, access for disabled viewers (as through closed captioning or video descriptions), charitable activities, emergency warnings and services, and the like. The FCC should require completion of a relatively simple forin to ensure accurate and uniform accounting, and FCC staff should sanction those stations that have failed to disclose, or that have done so maccurately.

A special advantage of disclosure requirements is that they appear to fit well with the emerging commumications market insofar as they allow maximum flexibility and do not impose requireinents that may be rapidly

164. See Percival ET AL., supra note 145, at 611-16.

165. See Khanna et al., supra note 137, at 243.

166. See GunNINGHAM ET AL., supra note 20, at 296-300. 
outrun by changing technologies. Even in a period in which broadcasters are akin to Time and Newsweek, such requirements would inake a good deal of sense as a means of creating some democratic pressure for improvement. ${ }^{167}$ Of course it is reasonable to think that, as the inarket evolves, disclosure requirements should be placed on all programmers, and not be limited to broadcasters. The hope-based on good results in the environmental context-would be that such requirenents would produce a kind of "race," at least in soine markets, to do inore and better.

\section{Of Realism and Ineffectiveness}

Is the hope realistic? People did not anticipate that the Toxic Release Inventory (TRI) ${ }^{168}$ would by itself spur behavioral changes; the question is whether the same forces might operate here. The answer depends on whether the mechanisins that have produced significant voluntary changes in the environmental arena will also be triggered in this setting.

In order for voluntary improvements to occur, the disclosure requireinents inust be accoinpanied by political activity or existing norms that will increase public interest programming. With respect to the TRI, wellorganized groups have been able to threaten, or to use, publicity so as to induce companies to undertake voluntary reductions. Environinental groups have inobilized when disclosure shows high levels of toxic emissions; anticipating this, companies have reduced emissions voluntarily. ${ }^{169}$ Thus, the effect of the TRI has been to draw private and perhaps governinental attention to the inost serious polluters, who have an incentive to reduce on their own. Once this process is underway, there has been a kind of coinpetition to produce further reductions, as each polluter seeks to be substantially below the group of nost serious polluters.

The question is whether the same might happen here. The answer depends first on the existence of external inonitoring and second on the

167. An obvious question is whether, if the case for disclosure has been made out, similar requirements ought to be imposed on magazines and even newspapers. Indeed, the same question might be asked about economic incentives and voluntary self-regulation, as diseussed below. I do not discuss these questions here. For those who believe that there is increasingly little difference between television and print media, it might seem that if requirements of this sort are not desirable for the latter, they are also undesirable for the former. The best response to this argument is in BoLlinger, supra note 7 , at 85 , with the suggestion that the different regulatory regimes for the broadcast and print media are well-suited to two different images of press freedom, one image involving democratic selfgovernment, the other involving a form of economic laissez-faire. Bollinger believes that the existence of two parallel regulatory regimes makes appropriate space for each of these images, and that if one regulatory regime goes wrong (through, for example, excessive regulation of television, or an excessive "race to the bottom" in magazines), the other can serve as a corrective. See id. at 128-32. This Article is in the general spirit of Bollinger's approach, but it attempts to develop more flexible tools for implementing it, tools that are better adapted to the emerging television inarket.

168. 42 U.S.C. $\$ 11023$ (Supp. III 1997).

169. See PERCIVAL ET. AL., supra note 145, at 612-16; Hamilton, supra note 145, at 106-19; Khanna et. al., supra note 137 , at $243-44$. 
power of the monitors to impose reputational or financial harm on broadcasters with poor records. ${ }^{170}$ The external monitors may include public interest groups seeking to "shame" badly performing broadcasters; they may include rivals who seek to create a kind of "race to the top." Froun the disclosures, it should be clear which broadcasters are doing least to proinote the public interest, and perhaps those broadcasters will be specially targeted by private groups and competitors. The ultimate effect cannot be known a priori. If public interest organizations, and viewers who favor certain programming, are able to inobilize, perhaps in concert with certain meinbers of the mass media, substantial behavioral effects might be expected. It is even possible that a disclosure requirement would help create its own monitors.

These are analogies between environmental disclosure and disclosure of public interest activities, but there are important differences as well. It is possible that toxic releases are such a salient and easily quantified public "bad" that a political response is quite likely; perhaps a failure to provide public interest programming is a far less salient "bad." An announcement that a certain conipany has emitted a certain level of toxic pollutants may produce a rapid public outcry and considerable media attention; an announcement that a certain station has failed to provide free air time for candidates nay be inet with public indifference, even a yawn. Partly this is because acts seen worse than omissions (whatever the conceptual difficulties with making the distinction). Partly this is because the harmful effects of toxic pollution seem serious and real in the abstract, a point that is far less clear with a particular station's refusal to provide programming for children. The harmful effects of that refusal might be mitigated by the fact that programming for children is available on other stations, and indeed any problems caused, or not solved, by profit-seeking television companies might well be remedied by other sources (newspapers, magazines, the Internet). These points suggest that information disclosure inay well work better in the environmental context, in which the nature and extent of the problem make public concern far more likely.

In short, companies are responsive to economic incentives, as well as to existing social norms. Information disclosure works best when inarket pressures, or political pressures, are likely to result in significant costs for those whose performance is poor. In the environmental context, disclosure strategies have worked well when companies have feared their consequences. ${ }^{171}$ In the context of television, the risk is that disclosure will have no effects at all-a purely symbolic measure. Indeed, the very collective action problems that argue for public service obligations raise the possibility that an information systenı will be quite ineffectual.

170. See GUNNINGHAM ET AL., supra note 20, at 296-300; Khanna et al., supra note 137, at 243.

171. See GUNNINGHAM ET AI., supra note 20 , at 68-69. 
But in view of the relative unintrusiveness of a disclosure requirement, and the flexibility of any private responses, this approach is certainly worth trying. At worst, little will be lost. At most, something will be gained, probably in the form of better programming and greater information about the actual performance of the broadcasting industry-and also about the circumstances in which disclosure requirements will be effective on their own. In light of the aspirations of most viewers, the possible result of disclosure will be to improve the quality and quantity of both educational and civic programming in a way that promotes the goals of a wellfunctioning deliberative democracy. The most effective system of disclosure would work in concert with well-organized advocacy groups willing to publicize poor performance and to bring general attention to those who do both worst and best.

\section{$\mathrm{V}$ \\ ECONOMIC INCENTIVES}

In this Part, I explore the possibility that broadcasters might meet their public interest responsibilities, not through a set of uniform requirements, but through economic incentives. As we will see, the most creative and promismg approach, modeled on recent environmental reforms, involves "play or pay," in which broadcasters are given a choice between complying with public interest requirements or paying soineone else to put public mterest programming on the air. I begin with a discussion of "play or pay," and then inove to a inore ambitious treatment of the alternatives, growing out of the law of tort, and posing a debate between inarket-suppressing and inarket-suppleinenting approaches.

\section{A. OfNature and Coase}

Ronald Coase's work on efficiency, free trades, and transaction costs originated in the area of communications, and in particular, in an attack on the FCC; but it has been most influential in the environmental arena. ${ }^{172}$ In that area, there has been a great deal of dissatisfaction with rigid governmental commands, and there has also been an unmistakable movement in the direction of inore flexible economic instruments, which are likely to be far more efficient. ${ }^{173} \mathrm{~A}$ command might say, for example, that every coalfired power plant must reduce its sulfur dioxide emissions by fifty percent, or that it must use technology of a governmentally specified kind. With respect to environmental protection, incentives typically coine in two different forms: pollution fees, imposed on those who produce environmental

172. See R.H. Coase, The Market for Goods and the Market for Ideas, 64 AM. ECON. REv. PAPERS \& Proc. 384 (1974), reprinted in R.H. COASE, ESSAYS ON ECONOMICS AND ECONOMISTS 64 (1994); see also R.H. Coase, supra note 65.

173. See GUNNINGHAM ET AL., supra note 20 , at 391-421. 
harm, and tradeable pollution right or "licenses," given to those who produce pollution. Under the pollution fee model, the government might say that companies must pay a certain amount per unit of sulfur dioxide emission. Under the tradeable pollution right model, the government might say that each company is permitted to emit a certain specified amount of sulfur dioxide, but that its permission, or right, can be bought and sold on the free market. In the former model, it pays to reduce pollution simply im order to reduce the level of the tax. In the latter model, it also pays to reduce pollution because the reduction can be used to engage in more of the relevant activity or in order to obtain money from another who cannot reduce so cheaply. Fees or tradeable licenses should create good dynamic incentives for pollution reduction, and also move environmental protection in the direction of greater cost-effectiveness. ${ }^{174}$

There is a complex literature on the choice between pollution fees and tradeable emission rights. ${ }^{175}$ The solution depends largely on an inquiry mto what the government knows and does not know. ${ }^{176}$ In general, a fee is better if the government is able to calculate the damage done per unit of pollution but has difficulty in calculating the appropriate aggregate pollution level. In those circumstances, a fee is better because the government is unlikely to err in setting it, whereas a system of tradeable permits will produce mistakes. By contrast, a tradeable permit is better if the government knows the appropriate aggregate level, but is unable to calculate the damage done per unit of pollution. In either case, the government can capitalize on the informational advantage held by private busmesses participating in pollution control, so as to allow them to decide on the most effective, least expensive method of achieving any particular pollution reduction. If, under a system of pollution fees, it is extremely expensive for Company $A$ to reduce its current level, it may choose to pay a high tax. If the system is one of tradeable pollution rights, it may simply pay someone else, capable of reducing pollution more cheaply, to produce the relevant reduction mstead. For any desired level of reduction, a system of economic incentives should produce the right result at a lower cost, by allocating burdens to those most able to bear them.

\section{B. Taxes, Public Bads, Hot Potatoes, and Cold Spots}

Although the FCC has experimented with allocating commumications rights via auction, little thought has been given to the possibility of using economic incentives to promote public interest goals in the

174. See William J. Baumol \& Wallace E. OAtes, The Theory of Environmental Policy 177 (2d ed. 1988).

175. For an overview, see Richard H. Pildes \& Cass R. Sunstein, Reinventing the Regulatory State, 62 U. CHI. L. REv. 1, 72-85 (1995).

176. See StepHEN BREYer, REgULATION AND ITS REFORM 271-83 (1982). 
commumications market. In principle, however, both the fees approach and the license approach may well be preferable to government commands. At least this is so if we think of public interest programming as a "good," which people should pay for failing to produce, just as pollution is a "bad," whicli people should pay for producing. Consider educational programming and free time for presidential elections. Suppose, for example, that $\mathrm{ABC}$ is in an especially good position to produce high-quality programming for children, whereas CBS is in an especially good position to promote high-quality programming involving presidential elections. Rather than requiring both $\mathrm{ABC}$ and $\mathrm{CBS}$ to produce educational programming and programming involving presidential elections, the government might allow each to pay a fee, or a tax, if it is to be relieved of the requirement of providing one or the other. This is the "tax" model of public interest programming. Alternatively, the government might adopt the tradeable emission right model, and allow CBS to sell $\mathrm{ABC}$ its obligation with respect to educational programming, while permitting $A B C$ to sell $C B S$ its obligation with respect to presidential elections.

A large problem with a tax is that it is very hard to calculate. Should the government use market measures of some kind, or attempt to measure the public loss, or lost public gam, from the broadcasters' behavior? Either approach would be quite difficult. In these circumstances, the simplest approach would be for the government to experiment with "play or pay" approaches, in which broadcasters have a presumptive obligation to provide public service programming but can buy their way out by paying someone else to provide that programming instead. Such approaches have had considerable success in the environmental area, despite a number of familiar reservations. ${ }^{177}$ People have objected, for example, that emissions trading will make an unfortunate "statement" about pollution, thus legitimizing it, ${ }^{178}$ or that trading will result in the concentration of pollution in dangerous "hot spots," 179 or that the administrative burdens of a trading system are overwhelming. ${ }^{180}$ Practice has generally shown these objections to be unconvincing. ${ }^{181}$ If there is an analogy between environmental protection and broadcasting regulation, ${ }^{182}$ a system in which those who do not provide public interest programming must pay a kind of "fee" has an important advantage, because it is so much more flexible than one in which the government imposes uniforn obligations on everyone. In this respect, a

177. See Robert N. Stavins, What Can We Leam from the Grand Policy Experiment? Lessons from $\mathrm{SO}_{2}$ Allowance Trading, J. EcoN. PERSP., Summer 1998, at 69.

178. See Steven Kelman, What Price Incentives?: Economists and the Environment 110-65 (1981).

179. See Stavins, supra note 177 , at 82 .

180. See id. at 80 .

181. See id. at 79-82.

182. See HAMILToN, supra note 45 , at $285-322$, for an instructive discussion. 
system of "play or pay" seems to be the most cost-effective means of proInoting public interest goals, just as emissions trading is the most costeffective ineans of reducing pollution. For those who dislike it, a public interest obligation can be treated as a kind of "hot potato"; fortunately, froin their point of view, it is one that they can transfer to others, as a gift accoinpanied by cash.

It is possible to respond, as has been conventionally thought, that public interest responsibilities are a general part of the public trust and not alienable, and that broadcasters should not be permitted to "buy their way" out of those obligations. But it is unclear what content to give to this statement; the question is what concrete harm would be created by a right to "pay" rather than "play." If the "play or pay" option had corrosive effects on the norms of the broadcasting industry, by inaking people take public responsibilities less seriously, that would indeed be a problem; but there is little reason to believe that the option would have this effect. The simple question is this: What if a broadcaster were willing to give ten million dollars to PBS in return for every minute, or every thirty seconds, of relief from a public interest responsibility? At first glance, the nation would be better off as a result, simply because the result would be to provide the same level of public interest broadcasting at lower cost. Any objection to a systein of tradeable rights would have to be inore subtle.

A conceivable problein with an econormic incentive in this context is that it inay undermine the general purpose of public interest programming by producing a situation in which that programming is confined to a small subset of stations_-"cold spots"-in a kind of communications equivalent, or converse, of the "hot spot" problem in the environmental area. ${ }^{183}$ The "hot spot" problein arises when trades result in a concentration of pollution in a single area, with serious adverse health effects; it is generally agreed that steps inust be taken to ensure that this does not happen. ${ }^{184}$ In the coininunications context, the problein will arise if all of the widely viewed broadcasters end up selling their obligations to a single station or set of stations. This is undesirable if it results in a kind of "ghettoization" of public interest programming and if it is believed, as seeins quite sensible, that all or nost viewers ought to have access to some public interest programming.

A second problein is both conceptual and administrative. When a trade is inade, what is being traded? Perhaps it seems simplest, and inost sensible, to trade minutes for minutes. But all broadcast minutes are not the sanie. An "internal" trade could be one in which ABC (for example) trades an hour of prime-time programming for an hour of 3:00 A.M. programming; an external trade could involve a transfer of one hour of $\mathrm{ABC}$ 's

183. See Pildes \& Sunstein, supra note 175 , at 24 .

184. See, e.g., Stavins, supra note 177 , at 82. 
highly popular evening hours to (say) FOX's far less popular show in the same period. Steps must be taken to ensure that in any trade, there is an equal public interest benefit for public interest loss. Perhaps a test of audience shares-"viewer-per-viewer" trades-is the best way to start.

An approach of this kind would have the fortunate consequence of helping to handle the "cold spot" problem as well. Part of the problem can be handled by momitoring the sales to make sure that a high-viewer broadcaster is trading to other high-viewer stations. If the "minute-for-minute" trades were adjusted to take account of the number of viewers, a trade to a low-viewer station would be especially expensive. Demographic considerations could play a role as well. The details are less important than the suggestion that a creative administrative solution could reduce the relevant problems, just as these have been handled in the environmental arena.

\section{Economic Incentives and the Constitution}

What is the relationship between economic incentives and the First Amendment? A direct tax on undesirable programming, or on the failure to provide desirable programming, would raise serious constitutional questions. This is because the tax would be a regulation of speech on the basis of content. Whether such a regulation would be unconstitutional should turn on many of the questions raised in debates over the legitimacy of the "fairness doctrine," designed to compel coverage of serious issues and an opportumity to speak for opposing views. ${ }^{185}$ Many people have argued that with decreasing scarcity, the fairness doctrine is no longer legitimate, if it ever was. ${ }^{186}$ If this objection is correct, an economic incentive in the form of a tax would be questionable too.

This point raises the question why, if a tax would be constitutionally problematic, a system of "play or pay," which has similar motivations and consequences, would not be constitutionally problematic as well. The intuition might be that a tax is a direct penalty on a certain programming content, whereas "play or pay" simply provides an alternative ("pay") to a legitimate mandate. But this seems to be a forn of wordplay. If a tax is questionable, "play or pay" should be questionable as well.

My suggestion here is that there should be no constitutional objection to the extent that the government is acting, in a viewpoint-neutral fashion, to promote educational goals and attention to civic affairs. Current law gives no clear answer to that question. ${ }^{187}$ For those who believe that the

185. See Syracuse Peace Council v. FCC, 867 F.2d 654 (D.C. Cir. 1989), for an outline of the issues.

186. This is the FCC's current position. See id. at 656.

187. See Turner Broad. Sys., Inc. v. FCC, 520 U.S. 180, 191 (1997) (upholding "must carry" rules as effort to promote widespread dissemination of information from a multiplicity of sources, but emphasizing that the rules are content-neutral). For a general discussion, see CASS R. SUNSTEIN, ONE CASe At A Tme 172-207 (1999). 
government is prohibited from favoring programming of a particular content, "play or pay" should be unacceptable. The problem with this view is that it seems to convert the First Amendment into a species of Herbert Spencer's Social Statics, ${ }^{188}$ in a way that loosens the connection between the free speech principle and underlying democratic goals. If the First Amendment is associated with democratic self-government and with deliberative democracy, "play or pay," of the sort suggested here, would be perfectly consistent with the free speech guarantee. ${ }^{189}$

\section{Expanding the Viewscreen: A Glance at the Cathedral}

Thus far I have been exploring economic incentives by contrasting taxes and tradeable rights with command-and-control regulation. But if we wanted a more complete picture, we would widen the viewscreen a bit. In a classic article, Guido Calabresi and A. Douglas Melamed proposed four "rules" that courts might adopt for nuisance suits. ${ }^{190}$ Two of the rules come from a situation in which either the plamtiff or the defendant is given the relevant entitlement, and it is protected via a "property rule," in which case the entitlement could be reallocated only through a trade. ${ }^{191}$ The other two rules come from a situation in which either is given an entitlement protected by a "liability rule," in which case the entitlement could be reallocated through a legally forced exchange, at a price determined through the legal system (assumed to be the market price). ${ }^{192}$ Calabresi and Melamed also discuss "inalienability rules," in which no exchanges are permitted, either voluntarily or through the legal system. ${ }^{193}$

There is a great deal of room for exploring, through this lens, the system of public interest regulation. If public interest programming is desirable, and if certain programming is undesirable, it makes sense to think of ways of requiring broadcasters to pay "damages" or instead requiring the taxpaying public to pay for better programming. Valuation, of course, is a serious problem. Suppose that certam programming (educational or civic, for example) is a public good, producing positive externalities, and that certain programming (violent material, for example) is a public bad, producing negative externalities. How can the government assign monetary values to the desirable and undesirable effects? Is it constitutional for the government to do so? These questions are hard enough in the area of torts;

188. SPENCER, supra note 117.

189. I discuss the relationship between democratic goals and regulation of speech in SuNSTEIN, supra note 68 , at $17-51$.

190. See Guido Calabresi \& A. Douglas Melamed, Property Rules, Liability Rules, and Inalienability: One View of the Cathedral, 85 HARv. L. REv. 1089 (1972).

191. See id. at 1106.

192. See id at 1107 .

193. See id. at 1111-15. 
they are far harder in the context of broadcasting. I restrict inyself here to a comparison of some leading alternatives.

Rule 1. The government requires all broadcasters to provide public interest programming; no bargaining is allowed.

Comment: This is the traditional model, with the debate being about its scope; the number of obligations was sharply reduced in the $1980 \mathrm{~s}$, but without rethinking the basic model. Under this systern, the public's interest in the relevant programming ${ }^{194}$ is protected by an inalienable property rule. The entitlement is granted to the government, and it is entitled to mandate broadcaster performance. Broadcasters have a kind of "split" property right; they own the right to broadcast as they choose (in general), but the public has a kind of lien on the property, giving it ownership rights over certain areas. Those who like the traditional approach appear to think that it has good social consequences, by, for example, ensuring that public interest programming is not relegated to unpopular times and channels, and also that it has desirable "expressive" effects, by, for example, affirming the status of broadcasters as public trustees. As we have seen, it also has several problems; its rigidity is likely to lead to inefficiency, and it may well produce unintended adverse consequences, as in the case of the fairness doctrine.

Rule $2 a$. The government requires broadcasters who do not provide public interest programming to pay a kind of "damage award" to be determined by the government and then used to fund public interest programming by others, such as PBS.

Comment: Under this approach, the public continues to have the relevant entitlement, which is protected by an unusual liability rule. The broadcasters' failure to provide educational programming for children or free air time for candidates would count as a kind of social harm for which broadcasters would have to pay. (The same might be said of the provision of violent or sexually explicit programming, though here the First Amendment problems would be quite serious.) One problem with this approach is the need to calculate the level of the "damage award." There are no clear market measures for this amount, which will therefore have a level of arbitrariness.

Rule $2 b$. The government requires each broadcaster to provide a certain level of public interest programming, but permits broadcasters to transfer their obligations (accompanied by money) to others, at a marketdetermined rate.

194. I am so describing it for convenience, without making any normative judgment. 
Comment: This is akin to Rule $2 \mathrm{a}$, in the sense that the public has the relevant entitlement, which is protected by a kind of liability rule, but here the inarket, rather than the legal systein, determines the value of not playing the public interest programming. One station might sell to another its obligation to provide, say, one lour of educational programming; the selling station would pay the inarket-determined amount to ensure that the buying station will find it worthwhile to take on the new duty. This kind of inarket determination could be a substantial advantage in light of limited information on the government's part, as the government is in an extremely poor position to calculate any such "damage award."

As compared with Rule 1, a potential problem with this approach is that some people may avoid the stations that "play" and may not see the relevant programming at all. On the other hand, the empirical question remains whether under Rule 1 inost inembers of the viewing audience will see and benefit from the inandated programming.

Rule 2c. The government establishes a minimum total content of public interest broadcasting on broadcast networks each year (for example, 6 hours of free air time for candidates, 150 hours of educational programming for children); assigns initial obligations to each broadcaster; and then permits broadcasters to trade the obligations at market-determined prices.

Comment: This is very close to Rule $2 b$; the only difference is that it is a precise analogy to certain initiatives in environmental law, in which the government establishes a maximum level of pollution in the relevant area, provides pollution permits, and then allows trades among polluters. ${ }^{195}$ A disadvantage of this approach, as compared to Rule $2 \mathrm{a}$, is that it may be harder to calculate the total level of appropriate programming than to decide on the appropriate tax for those who do not "play." On the other hand, the opposite may be true. ${ }^{196}$ An additional difficulty, as discussed above, is that broadcasting hours are not fungible. An hour of children's programming is much less valuable at 3:00 A.M. on Monday than at 9:00 A.M. on Saturday.

Rule 3a. The government pays broadcasters (at reasonable but government-determined rates) to provide public interest programming.

Comment: Under this approach, the broadcasters have the relevant entitlement, which is protected by a liability rule. The broadcaster owns the entitlement, but the government is permitted to obtain a forced exchange,

195. This is the acid deposition program under the Clean Air Act, 42 U.S.C. $§ 7651$ (1994).

196. These are brief notes on a complex issue. For details in the environinental context, see Jonathan Baert Wiener, Global Environmental Regulation: Instrument Choice in the Legal Context, 108 YALE L.J. 677, 706-35 (1999). 
just as it is in the general law of eminent domain. In fact it is possible to see soine kind of payinent as the constitutionally coinpelled solution, at least if the right to provide such programming as broadcasters choose is taken to be, by constitutional decree, an entitlement in broadcasters. For example, the government might be able to compel coverage of important issues, or attention to the needs of children, or programming involving emergencies, but the public has to pay.

Interestingly, the government appears not to have tried this approach, at least not as a general rule. An advantage of this approach is that it should not be difficult to calculate the value of the exchange; the market will help answer that question. This is an important advantage over Rule 2a. On the other hand, Rule $3 \mathrm{a}$ has probably been resisted, as compared with Rules 1, $2 \mathrm{a}$, and $2 \mathrm{~b}$, with the thought that because broadcasters are beneficiaries of public largesse, they should not be paid to promote public interest goals. This is of course a distributional concern, and the underlying judgmentthat "broadcasters," rather than "taxpayers," should pay-is not clearly correct in light of the complexity of the incidence of the burden imposed under Rules $1,2 \mathrm{a}$, or $2 \mathrm{~b}$. The burden under the latter rules does not simply fall on "broadcasters," but more likely on advertisers and ultimately on consumers-perhaps to the benefit of those who advertise in newspapers and on cable. Rule 3a might be preferable if it is amended as suggested in Rule 5a, which would require broadcasters to buy spectrum rights.

An important difference between Rule $3 a$ and Rules $2 a, 2 b$, and $2 c$ is that the latter rules give the entitlement to the public, in a way that may have important psychological effects on any trades. The initial allocation of the entitleinent creates an endowment effect and tends to "stick," 197 in part because of its legitimating function. Those who favor public interest obligations might be skeptical of Rule 3 a for this reason alone.

An additional problem with this kind of system is that it may provide broadcasters with an incentive to produce less public interest broadcasting on their own than they otherwise would, or at least to understate the amount that they would voluntarily provide. In an unrestricted market, political and shareholder pressures, conscience, and advertiser and viewer deinand will result in a nontrivial amount of public interest programming. ${ }^{198}$ But if the government proposes to pay broadcasters for whatever public interest programming they provide, voluntary service may be substantially reduced. This is a pervasive problem with paying people to do good or not to do bad; the payment may induce less of the good or more of

197. See Richard H. Thaler, The Winner's Curse: Paradoxes and Anomalies of ECONOMIC LIFE 63-66 (1992).

198. See national association of Broadcasters, Broadcasters: Bringing Community SERVICE HoMe 2-4 (1998). 
the bad. The question for Rule 3 is whether it is possible to generate a "basehne production level" from which any subsidy could be calculated.

Rule $3 b$. The government must-and does-buy the right to ensure public interest programming, at market-determined rates.

Comment: This is a variation on $3 \mathrm{a}$ in the sense that it transforms the broadcasters' entitlement into one protected by a property rule. It is akin to a system of free markets in broadcasting, but with two qualifications: Broadcasters are not required to pay for their entitlement in the first instance, and government stands ready to compete with others who seek to obtain access to viewers. One advantage of Rule $3 \mathrm{~b}$ over $3 \mathrm{a}$ is that it operates entirely on the basis of market-determined prices; no one has to calculate a special government rate. But if one believes that existing fare is not problematic, the government's purchases will be wasteful. And those committed to public interest programming may object that the government will not purchase enough (unless this is specified in some way in advance); they may also object that so long as licenses are being given away free, other rules, not giving a "windfall" to broadcasters, are better.

Rule 4. Broadcasters provide such public interest broadcasting as they choose, including none at all.

Comment: Under this approach, the broadcasters' interest is protected by a property rule. Broadcasters own the relevant entitlement. Just as occurs in an ordinary market, people can pay broadcasters to provide public interest programming, at inarket-determined prices. The problein with this approach is that the market price might be too high, for all of the reasons discussed in Part I.B of this Article. This approach is similar to Rule $3 b$, except that the governinent does not stand ready to ensure a certain level of public interest programming.

Rule 5a. Broadcasters must buy, via auction, the right to broadcast, and once they do that, they can provide such public interest broadcasting as they choose, including none at all.

Comment: This is a genuine market solution. It does not involve a governmental "giveaway" of a scarce resource, and after the valuable commodity has been purchased, free trades are allowed. It seems to have all the advantages of Rule 4, with the further advantage that the valuable property right is purchased rather than simply conferred. The probleins with this approach should be easy to identify from Part I.B of this Article. In short, the result may be insufficient public interest programming, partly because of the endowment effect, partly because of collective action problems, partly because of the limitations of the market model in the 
communications industry, and partly because of public aspirations diverging from private consuniption choices.

Rule 5b. Broadcasters must buy, via auction, the right to broadcast, but once they do that, they may be asked or (if for some reason necessary) compelled to provide public interest broadcasting at market-determined prices.

Comment: This is quite similar to Rule 5a. The difference is that the government stands ready to pay for public interest programming on broadcast stations, at niarket prices; and if broadcasters for sonie reason refuse, the government can force an exchange. Under Rule 5b, part of the entitlenent is owned, but protected only by a liability rule. This approach is in one sense a cousin of Rule $2 \mathrm{~b}$. The major difference is that here the taxpayers are paying for public interest programming (at the same time that they receive noney from the sale of the spectrum), rather than "broadcasters." The noost inportant difference is therefore distributional. As noted above, that difference is more complex than it seems in light of the fact that when a burden is imposed on "broadcasters," their advertisers are likely to be paynig nuuch of the bill, and the result will be complex effects on consumers, on other communications outlets, and on advertising choices. There is no simple redistribution, in Rule $2 b$, from "broadcasters" to the "public."

Rule 5c. Broadcasters must buy, via auction, the right to broadcast; once they do so, they may be subject to public interest obligations, but they can pay a "damage award," to be used by some other station to support public interest programming, if they fail to fulfill their obligations themselves.

Comment: This should also decrease the amount paid for the entitlement, as compared with Rule 5a. This is a "play or pay" version of Rules $5 \mathrm{a}$ and $5 \mathrm{~b}$. The problent here lies in determining the level of any such "damage award." This approach is in one sense a cousin of Rule $2 \mathrm{a}$, as a "play or pay" systenı.

***

A full understanding of these possibilities would greatly facilitate both conceptual and empirical inquiry. Undoubtedly a choice among the various options should depend partly on the particular public interest obligation nivolved; for example, a requirement of emergency warnings might take the form of Rule 1 , whereas a requirement of free air time for candidates might be some conbination of Rules $1,2 b$, and $5 b$. The analysis thus far suggests that Rules $2 b$ and $5 b$ have special advantages over the alternatives. Rule $2 b$, the basic "play or pay" system, seems well-suited to the current period, as a kind of interims improvement over the regulatory 
status quo. In some areas, Rule $5 \mathrm{~b}$ may well be better $\mathrm{m}$ the longer term, as broadcasters come to resemble general-interest magazines. Movement in the direction of selling the spectrum, rather than giving it away to preselected owners, would also be highly desirable.

\section{E. A Brief Note on Cultural Policies and Cultural Subsidies}

The immediately preceding discussion raises obvious questions about when and whether it is appropriate for the government to devote collective resources to the proinotion of a better cultare, and in particular, to promotion of a better democratic order. A "cultural policy" might, for example, involve the use of taxpayer funds to promote opera or high art, perhaps by subsidizing musicians and artists, perhaps by making it easier for poor people and children to afford to go, perhaps by creating a situation in which people can attend at vastly reduced rates or even for free. In Washington, D.C., for example, people can attend public inuseums, including those devoted to historical and democratic issues, for free, a practice that creates a distinctive atmosphere for people who visit the nation's capitol. Such visits would have a different tone if, for example, it were necessary to pay three dollars to attend the National Archives, which house the original Declaration of Independence, Constitution, and Bill of Rights.

The general topic of public funding of cultural endeavors is highly controversial and has received considerable attention. ${ }^{199}$ The discussion thus far suggests, at a minimum, that such policies should be less controversial when individual consumption choices involve a collective action problem, or when in their capacity as citizens, 1nost people urge their government to promote some activity in order to proinote genuinely public aspirations. The argument is most secure when those aspirations involve democracy itself. There is reason for the government to support prograinming that promotes public education about civic affairs, whether or not that programming is provided by markets themselves; and at a minimum, government subsidies of this kind are firmly supported on theoretical grounds. ${ }^{200}$

VI

VoluntaRy Self-Regulation: AsPirations, Trustees, AND "WINNER-TAKE-LESS" CODES

In this Part, I discuss the possibility of promoting public interest goals through voluntary self-regulation, as through a "code" of conduct to be issued and enforced by the National Association of Broadcasters (NAB), or

199. See, e.g., Ronald Dworkin, Can A Liberal State Support Art?, in A MATter of PRINCIPLE 221, 221-35 (1985).

200. See Baker, supra note 60, at 383-408. 
perhaps by a wider range of those who produce television for the American public. The idea of voluntary self-regulation - of television and content on the Internet-has received growing attention in many nations. ${ }^{201}$ For many decades, in fact, the NAB did indeed impose a code, partly to promote its econormic interest (by raising the price of advertising), partly to fend off regulation (by showing that the industry was engaged in self-regulation), and partly to carry out the moral commitments of broadcasters themselves. ${ }^{202}$ And voluntary self-regulation has played a role in numerous areas of media policy, including, for example, cigarette advertising, children's advertising, family viewing, advertising of hard liquor, and fairness in news reporting. ${ }^{203} \mathrm{~A}$ code has a great deal of potential. Above all, it could address a far greater number of problems than could an economic incentive (for First Amendment reasons), and it appears to have far more potential for producing good, and reducing bad, than a disclosure requirement.

For example, a code could address all public interest obligations mentioned thus far, but also attempt to protect against sexually violent material, against subliminal advertising, against sensationalistic treatment of politics, and against a wide range of other problems with television. The question is whether it is possible, in the current era, for broadcasters to overcoine soine of the unfortunate effects of the inarketplace with voluntary measures. An underlying question, likely to be faced in many areas of regulatory policy both doinestically and internationally, is whether a code would work as a kind of unfortunate cartelization or instead as protection against an undesirable "race to the bottom."

A code might do a great deal of good, partly because of the likely existence of external monitors, partly because of a code's capacity to help develop a kind of internal morality likely to affect many of its signatories. A general lesson is that the antitrust laws ought not to be invoked too readily to prevent producers from undertaking cooperative action in circumstances in which competition is producing palpable social harms. In such contexts, a code can provide some of the advantages of government regulation, but do so in a more flexible and better-informed fashion. It is hazardous to invoke the antitrust laws to prevent an industry from providing the kinds of benefits that might be provided, nore crudely and expensively, by direct regulation. ${ }^{204}$

201. See Goldberg et al., supra note 5, at 312. For a general discussion, see IAN AYRES \& JoHN Braithwaite, Responsive Regulation: Transcending the Deregulation Debate 103-16 (1992).

202. See infra Part VI.B.3.

203. See Campbell, supra note 21, at 715-37.

204. See FRANK \& COOK, supra note 23, at 225-27. 


\section{A. The Problem and a Recently Emerging Strategy}

Notwithstanding the qualifications described above, competitive pressures often can and do provide programming that people would like to see. In an era of cable and satellite television, and an increasingly large range of options, competitive pressures will be especially important in producing "niche" programming for people who have a particular interest in serious programming. The communications market increasingly resembles the market for inagazines; recall the possibility, in a digital market, of over one thousand stations. But competitive pressures have a downside. They can lead to sensationalistic, prurient, or violent programming, and to a failure to provide sufficient attention to educational values, or to the kind of programming that is indispensable to a well-functioning dernocracy ${ }^{205}$ This is so especially in light of the fact that a sinall relative advantage can lead to huge increases in viewers, a fact that presses television in tabloid-like directions. As Robert Frank and Philip Cook have suggested,

[i]ncreasingly impoverished political debate is yet another cost of our current cultural trajectory. Coinplex modern societies generate complex economic and social probleins, and the task of choosing the best course is difficult under the best of circumstances. And yet, as in-depth analysis and commentary give way to sound bites in which rival journalists and politicians mercilessly ravage one another, we become an increasingly ill-informed and ill-tempered electorate. ${ }^{206}$

It would be possible to respond to the harmful effects of competitive pressures in various ways. Probably the simplest response would take the form of voluntary self-regulation, through some kind of "code" of good programming; this approach is specifically designed to respond to the problems that can be introduced by market pressures. In various nations, including the United States, cooperative action has played a constructive role in situations of this kind. ${ }^{207}$ Though it has yet to receive inuch academic commentary, ${ }^{208}$ voluntary self-regulation via industry agreements is emerging as a regulatory strategy of choice, especially in the environmental arena. ${ }^{209}$ The EPA, for example, has encouraged coinpanies that produce pesticides to agree on pesticide reduction strategies, and here

205. See HamLton, supra note 45 , at 129-284 (discussing television violence).

206. Frank \& COOK, supra note 23, at 203.

207. See the discussion of ethical codes in Israel in Moshe NEGBI, The ENEMY WrTHIN 14 (1998) (discussion paper published by the Joan Shorenstein Center at Harvard University's John F. Kennedy School of Government). Note also that inany international bodies attempt to certify quality in a kind of cooperative action designed to reduce adverse effects of market pressures. See infra note 218.

208. An exception is Neil Gunningham \& Joseph Rees, Industry Self-Regulation: An Institutional Perspective, 19 LAW \& POL'Y 363 (1997). See also Ayres \& BRAITHWAITE, supra note 201, at 10132; Campbell, supra note 21, at 715-45.

209. See GuNNINGHAM ET AL., supra note 20, at 50-56, 300-10. 
the fact of broad agreement is crucial. ${ }^{210}$ California has attempted to deal with the problem of workplace accidents via a "cooperative compliance program" involving self-enforced safety plans on large construction projects. The result has been a significant drop in accident rates. ${ }^{21}$ Selfregulating agreements are now im place in Canada's system for forest management; in the Responsible Care program of the chemical industry, now operating in inore than forty countries; and in national regulation of nuclear power plants. ${ }^{212}$

What accounts for the increasing popularity of industry selfregulation, as part of the general project of "reinventing government"? Froin the industry's standpoint, self-regulation allows far 1nore flexibility than government mandates. From the standpoint of government, a special advantage of codes is that they avoid the kind of informational overload that comes froin government prescriptions. ${ }^{214}$ It is partly for this reason that voluntary agreements among companies have had good effects in the area of occupational safety and health. ${ }^{215}$ In a point of special relevance to television, codes also have been found to have the power to influence community attitudes in a way that tends to contribute to the development of a custodial ethic. ${ }^{216}$ Thus, codes have helped to develop an institutional 1norality that brings the behavior of industry inembers within a normative framework. ${ }^{217}$

Such cooperative action raises concerus about antitrust violations and self-interested profit-seeking under a public-spirited guise. This is of course a risk, but the antitrust law can go wrong when it prevents cooperative action that overcoines palpably adverse effects of 1narket pressures. Indeed, the International Standards Organization is designed specifically to ensure a form of cooperation to overcome those adverse effects; ${ }^{218}$ the question is whether that experience has communications analogues.

210. See id. at 300 .

211. See Gunningham \& Rees, supra note 208, at 369.

212. See GUNNINGHAM ET AL., supra note 20, at 51 .

213. See Special Issue on Self-Regulation, supra note 22.

214. See AYRES \& BRAITHWAITE, supra uote 201, at 110-12.

215. See John MENDENHall, REgulating OcCUPational Safety and HEalth 41-48 (1989); JoSEPH V. ReEs, REFoRMing THE WORKPLACE: A STUDY OF SELF-REgUlation IN OCCUPATIONAL SAFETY 80-82 (1988).

216. See GuNNINGHAM ET AL., supra note 20, at 162 .

217. See Gunningham \& Rees, supra note 208, at 371-72.

218. See, for example, Michael Prest, Profit Bows to Ethics, IndePEndent (London), Oct. 26, 1997, at 3, stating that:

Some of the world's biggest companies are putting their weight behind a new, verifiable code of conduct intended to answer mounting consumer criticism of the exploitative conditions under which the goods they sell are produced in poor countries. ... The code, called SA8000 (Social Accountability 8000), is the brainchild of the Council on Economic Priorities, an American public interest group, which tries to improve corporate responsibility. It has been drawn up by companies, non-governmental organisations, trade unions, and other interested groups, and is due to start operating next year. The code covers the basic issues of child 
My emphasis here is on allowing programmers and journalists to do what, in an important sense, they would actually prefer to do. It is worth underlining this point. Many journalists in the world of broadcasting would very much like to do better; ${ }^{219}$ competitive pressures are the problem, not the solution, and a voluntary code could help thein and the public as well.

\section{B. A Code: Sample Provisions}

The question is whether it might be possible to adopt a new code for broadcasting, specifically designed for the new commuincations market. There have been many precursors for voluntary self-regulation via codes. ${ }^{220}$ A new code might update the old NAB code, and help overcome current problems, without having the degree of tepidness of the existing "standards." A code imight even proinote soine of the goals associated with deliberative democracy.

What provisions might a new code include? The appropriate level of specificity is an important concern; especially clear provisions ("three hours of educational programming per week") risk excessive rigidity, whereas vague provisions ("reasonable efforts to provide educational programming for children") risk meaninglessness. Discussions of code1naking in general have stressed the need for "the public announcement of the principles and practices that the industry presumptively accepts as a guide to appropriate conduct and also as a basis for evaluating and criticizing performance. ${ }^{1221}$ This point argues in favor of a degree of specificity.

Consider the following possible code provisions, ${ }^{222}$ siinply for the sake of illustration:

1. Each broadcaster shall provide three hours of free air time for candidates during the two-1nonth period preceding the election. In return for free air time, candidates shall discuss substantive

\footnotetext{
labour, forced labour, health and safety, trade union rights, discrimination, discipline, working hours, and pay.... As the name SA8000 suggests, it is the first to be modelled on existing and widely accepted commercial standards such as IS09000, drawn up by the International Standards Organisation in Geneva, which is used to determine whether companies have the management systems to meet required product quality. But the real strength of the new approach is commercial sanctions. A company which adopts the code also agrees to be independently inspeeted to see whether it is abiding by the conditions laid down. It will be able to attract customers and gain a competitive advantage by advertising the fact that its factories and supphers meet the standard.
}

219. See SCHECHTER, supra note 50 , at 455-58.

220. See FINAL REPORT, supra note 19, at 114-16.

221. Gunningham \& Rees, supra note 208 , at 383.

222. These provisions are adapted but substantially revised from the more detailed code suggested by the Advisory Committee's FINAL REPORT, supra note 19. I believe that the provisions described there are too vague and tepid to be useful (I can attest that this was a quid pro quo for Committee agreement); for reasons discussed in the text, vague and tepid provisions create a high probability of futility and ineffectiveness. 
issues in a substantive way and must provide something other than short "sound bites."

2. Each broadcaster shall provide one hour of educational programming for children each day. Broadcasters shall attempt to ensure that children are not exposed to excessively violent programming or programming that is otherwise harmful to, or inappropriate for, children. Broadcasters shall avoid programming that encourages criminal or self-destructive behavior; they should also be sensitive in presenting sexual material that children might encounter.

3. News coverage shall be substantive and issue-oriented. It should not emphasize the sensational and the prurient. It should concern itself with claims and disagreements on matters of substance. Consistent with the exercise of legitimate station discretion, stations should not give excessive or undue attention to sensational accusations, or to reports of "who is ahead in the polls," at the expense of other issues.

4. Morbid, sensationalistic, or alarming details not essential to a factual report, especially in connection with stories of crime or sex, should be avoided. News should be broadcast in such a manner as to avoid panic and unnecessary alarm. News programming should attempt to avoid prurience, sensationalism, and gossip. Stations should make an effort to devote enough time to public issues to permit genuine understanding of problems and disagreements.

5. Violence should be portrayed responsibly and not exploitatively. Presentation of violence should avoid the excessive, the gratuitous, the humiliating, and the instructional. The use of violence for its own sake and the detailed dwelling upon brntality or physical agony, by sight or sound, should be avoided. Programs imvolving violence should venture to present the consequences to its victims and perpetrators. Particular care should be exercised where children inay see, or are involved in, the depiction of violent behavior. Programs should not present rape, sexual assault, or sexual violence in an attractive or exploitative light.

6. Broadcasters shall ensure that their programming is responsive to the needs of citizens with disabilities. To this end, broadcasters shall ensure that programming is accessible, through the provision of closed captioning and other means, to the extent that doing so does not impose an undue burden on the broadcaster. Particular efforts should be made to provide full access to news and public affairs programming. Hearing impaired citizens are 
sometimes at risk of a form of disenfranchisement, or even physical danger, because steps are not taken to ensure that television broadcasting is available to them. Stations should take special steps to ensure that information about disasters and emergencies is fully accessible to those who are hearing impaired, ideally in "real time."

7. Broadcasters shall cover international as well as domestic questions and give appropriate coverage to important events in other nations. They should recognize that purely national questions are often hard to evaluate without an understanding of the practices of others, and also that many questions, including those of war and peace, cannot be well-understood without the kind of background that comes from suitable attention to developments and events abroad.

\section{A Code: Problems and Prospects}

Such a code would of course raise many questions. The first would involve the problem of enforceinent. Without an enforceinent mechanism, a code might have no effect at all, indeed it might be a form of public deception. ${ }^{223}$ The enforcement question is a central part of the general inquiry into the preconditions for effective self-regulation. ${ }^{24}$

There are several obvious possibilities. The simplest would be for the $\mathrm{NAB}$ to undertake enforcement on its own, just as it did under the old code. It might, for example, give a seal of approval to those who are shown to comply with its provisions and deny a seal of approval to those who have been shown not to have complied. The NAB might also give special public recognition to those stations that have coinpiled an excellent public service record in the past year. Such recognition might be awarded for, among other things, meeting the needs of children $\mathrm{m}$ a sustained and creative way; offering substantive and extended coverage of elections, including interviews, free air time, and debates; offering substantive and extended coverage of public issues; and providimg opportunities for discussion of problems facing the local community. At the time of license renewal, a notation 1might be given to the FCC that there has been coinpliance or continumg or egregious noncompliance with the code. If the $\mathrm{NAB}$ is unwilling to enforce a code of this kind, ${ }^{225}$ perhaps a private group

223. See John Braithwaite, Responsive Business Regulatory Institutions, in BusINEss, ETHICs, AND LAW 91 (C. Cody \& C. Sampford eds., 1993) (discussing need for enforcement mechanisms); Campbell, supra note 21, at 756-69 (offering a skeptical view of the likelihood of success from any code). For a helpful overview of the preconditions for success, see Douglas C. Michael, Federal Agency Use of Audited Self-Regulation as a Regulatory Technique, 47 ADMIN. L. REv. 171 (1995).

224. See generally GunNIGHAM ET AL., supra note 20, at 155-72; Michael, supra note 223.

225. In the summer of 1998 and January 1999, the NAB decided not to oppose the idea of a code publicly and officially, but did suggest "serious concern" about any government effort to interfere with 
could take the initiative, both promulgating the code and publicizing it, and in that (modest) sense sanctioning violations. ${ }^{226} \mathrm{~A}$ special problem here is that in light of increasing competition from nonbroadcast programming sources, a code would not be in the economic interest of broadcasters even if generally adopted, and this is an unpromising fact for a code's effectiveness. ${ }^{27}$ Perhaps suppleinental enforcement will come from rivals of those who defect from the agreement and violate the code; this is a reasonable prediction in theory, and something similar has been found in analogous areas. ${ }^{228}$

Any enforcement by the $\mathrm{NAB}$ or even a private monitoring group would be inost likely to succeed if accompanied by external pressures of one sort or another. As in the case of disclosure requirements, the most promising possibilities include public interest groups able to mobilize relevant social norms and to focus media attention on derelict actors. ${ }^{229}$ Perhaps such activity would be accompanied by market pressures of various sorts, as consumer action has had significant effects on code enforcement in related areas. ${ }^{230} \mathrm{~A}$ degree of FCC interest in the existence of code violations would also help.

These points raise a related question: the appropriate scope of any such code. Undoubtedly such a code was less painful and easier to operate when three broadcasters exhausted the universe of television. Broadcasters now find themselves in competition with many other entertainnent sources, mcluding cable and the Internet. In these circuinstances, broadcasters are not likely to constrain themselves if their competitors are not similarly constrained; the competition for an audience for news is much affected by the existence of "tabloid television," and a rule limited to broadcasters would raise an obvious question about fairness. A broadcaster who ties himself to the mast may find himself with a significantly reduced audience. This point suggests that in the development of a code, broadcasters should perhaps be joined by the National Association of Cable Television.

By itself, however, a code limited to broadcasters should do considerable good, even if some broadcasters are reluctant to subscribe to it. When the market reaches the stage in which broadcasters are merely some of a

editorial freedom. See Paige Albiniak, Preparing for Battle, Broadcasting \& Cable, July 6, 1998, at 22; Fox Still Undecided on Leaving NAB, Expresses Concerns, CoMm. DAILY, Jan. 14, 1999, at 6.

226. This approach would have special advantages in light of the fact that some stations are not members of the NAB. For NAB stations that must compete with nonmember stations, a code creates an obvious competitive risk, and there is a continuing question whether it is possible to design strategies, public or private, to combat this risk.

227. See GuNNINGHAM ET AL., supra note 20, at 53-54 (emphasizing relation between economic self-imterest and self-regulation). .

228. See Gunningham \& Recs, supra note 208, at 403 (finding enforcement from competitors).

229. See id. at 390-92.

230. See id. at 391 (discussing hostile consumer action). 
large number of providers, with no distinctive status, it might make sense to think of a more general code (with suitable adjustments for particular kinds of programmers). ${ }^{231}$ It is worth underliming the point that, as in the context of disclosure, the likelihood of success will increase with the existence of third-party momitors, both public and private, and also with a threat of more intrusive action should it prove necessary..$^{232}$

\section{Notes on the First Amendment and Antitrust Law}

A code for television broadcasters might be thought to raise issues of both constitutional and antitrust law. The constitutional issues are relatively straightforward; the antitrust issues are a bit more complex. I offer a brief discussion here.

There is essentially no risk that a code of the sort suggested here would create serious First Amendment probleuns. By itself, a code is a private set of guidelines, and private guidelines by themselves raise no First Amendment issue. ${ }^{233}$ If a private group decides to impose restrictions on the speech of its members, and government is not involved, the First Amendment is irrelevant. ${ }^{234}$ Of course things would be different if government mandated any such code.

Nor would provisions like those described above be likely to violate the antitrust laws. The Department of Justice has so concluded, as have district courts in two important cases in which the private antitrust actions at issue involved parts of previous codes. The district court in American Brands, Inc. v. National Ass'n of Broadcasters ${ }^{235}$. examined a claim that code standards forbidding cigarette advertising violated antitrust laws. That court refused to issue an injunction against such standards. In American Federation of Television and Radio Artists v. National Ass'n of Broadcasters, ${ }^{236}$ the district court upheld code standards regarding advertising amied at children. The courts in both of these cases found the code standards reasonable and in the public interest. As I have noted, the most

231. For example, it is hardly clear that a station devoted to children should be required to provide free air time for political candidates.

232. See GUNNINGHAM ET AL., supra note 20, at 55-\$6.

233. See San Francisco Arts \& Athletics, Inc. v. United States Olympic Comm., 483 U.S. 522 (1987) (holding that the Constitution is not applicable to Olympic Committee); Rendell-Baker v. Kohn, 457 U.S. 830 (1982) (holding that the Constitution is inapplicable to private actors); Flagg Bros. v. Brooks, 436 U.S. 149 (1978) (noting that a private contract raises no First Amendinent issue). If a code is a product of government threat, and is effectively required by government, the First Amendment comes into play. There can be no question that a governmentally mandated code, not voluntary but taking the form outlined here, would raise legitimate constitutional problems. This does not necessarily mean that the First Amendment would be violated, but it does mean that the code would have to be tested for compliance with First Amendment principles, including constitutional limits on content regulation.

234. See cases discussed supra note 233.

235. 308 F. Supp. 1166 (D.D.C. 1969).

236. 407 F. Supp. 900 (S.D.N.Y. 1976). 
recent code's disintegration came at the hand of a 1979 antitrust action, in which the Department of Justice alleged that certain Code provisions violated the Sherman Act. But the Justice Department's complaint was quite narrow, and the court's decision ${ }^{237}$ would not invalidate a code of the sort suggested here. ${ }^{238}$ The television market's unique characteristics would allow a code of the sort porposed here to survive a "rule of reason" inquiry, which requires balancing of the relevant factors. It would be most reasonable to hold that any restrictions contained in the code would promote competition as well as various public interests goals, such as education of children, access for the handicapped, and other civic functions. ${ }^{239}$

\section{E. Less Puzzling Puzzles}

We are now in a position to disentangle the two puzzles discussed in Part I.B above. Why were broadcasters pleased that the proposed NAB code would violate antitrust laws? Why did they prefer rigid government mandates to a flexible, "play or pay" approach? The broadcasters on the Committee favored a code partly because they thought it a good idea in principle and partly because they had little to lose from it. Though generally "winners," they were selected for the Committee because of their commitment, through both words and deeds, to moderating some of the adverse effects of competition. They were vulnerable to "winner-take-all" effects insofar as they were reluctant to engage in certain competitive practices. In this way, a code might even help them. But the NAB would not like a meaningful code at all. The broadcasting industry as a whole would be hurt by such a code, especially because cable television would not be bound by it. Why should broadcasters, in an intensely competitive market, give a significant edge to cable? Especially if the result would be that cable could take a lot more, of the viewing audience than it now does? It is not surprising if broadcasters who supply a large degree of public interest programming believe that they would be net winners with a codeand if the broadcasting industry as a whole believes that it would be a net loser. Such an industry, cautious about invoking its own economic interest alone, is all too likely to invoke the antitrust laws (or the First Amendinent) for purely strategic and self-interested reasons.

This point also helps explain the Committee broadcasters' skepticism about "play or pay" alternatives. A set of rigid public interest requirements does not hurt them and may even help them, insofar as it places their competitors under legal duties that they would themselves meet voluntarily (because of their aspirations or because of the particular demands of their audience and their advertisers). A system of "play or pay" would mean that

237. See United States v. National Ass'n of Broadcasters, 536 F. Supp. 149 (1982).

238. See FinAl REPORT, supra note 19.

239. See id. at $120-21$. 
these broadcasters would be undercut by competitors who, unwilling to play, would pay-and capture a large audience share, in a version of "winner-take-most." But this is not a convincing objection to a system of "play or pay." It is true that some of those who "play" will be at a competitive disadvantage with respect to some of those who "pay" others to play instead. But by itself this competitive disadvantage is not worthy of concern, any more than we should be concerned when, in the environmental context, some of those who reduce pollution are at a competitive disadvantage with respect to those who, mstead of reducing pollution, pay a substantial fee to third parties who have reduced pollution. The question is what approach yields the best outcome for the public. If there is too little public interest broadcasting, or too much pollution, the solution is not the simple command to "play," or to "reduce," but to increase the price for failing to play or for failing to reduce. ${ }^{240}$

The best defense of a code of the sort I have discussed is that it would produce "winner-take-less" outcomes, in a way that would provide significant benefits for the public by diminishing sonie of the adverse effects of market competition and by strengtheming broadcaster norms in favor of obligations to children and to democratic values. And if this is so, it provides a general lesson about how voluntary private action might sometimes handle problems usually dealt with by direct regulation-and a lesson about the reflexive use of the antitrust laws to prevent producer cooperation. A key question is whether mechanisms might be created to ensure compliance with any such code.

\section{VII \\ A SUMMARY}

This discussion has ranged over a number of regulatory tools, and it may be helpful, by way of summary, to discuss them all briefly and at once. We have seen that both disclosure and codes have the advantage of ensuring a mimimal government role, im a way that reduces constitutional concerns and also allows a high degree of flexibility. The danger is that these remedies will have little effect; here the key question is whether there are good external monitors, able to impose reputational or other costs on those who do poorly. We have also seen that "taxes" on programming that does not serve public interest goals, and subsidies to programming that does serve such goals, can have similar effects. A principal problem with subsidies is that they create an mcentive not to provide such programming voluntarily. The following table charts the basic territory:

240. With the qualification that this could involve hot spots and cold spots, discussed supra at Part V.B. 


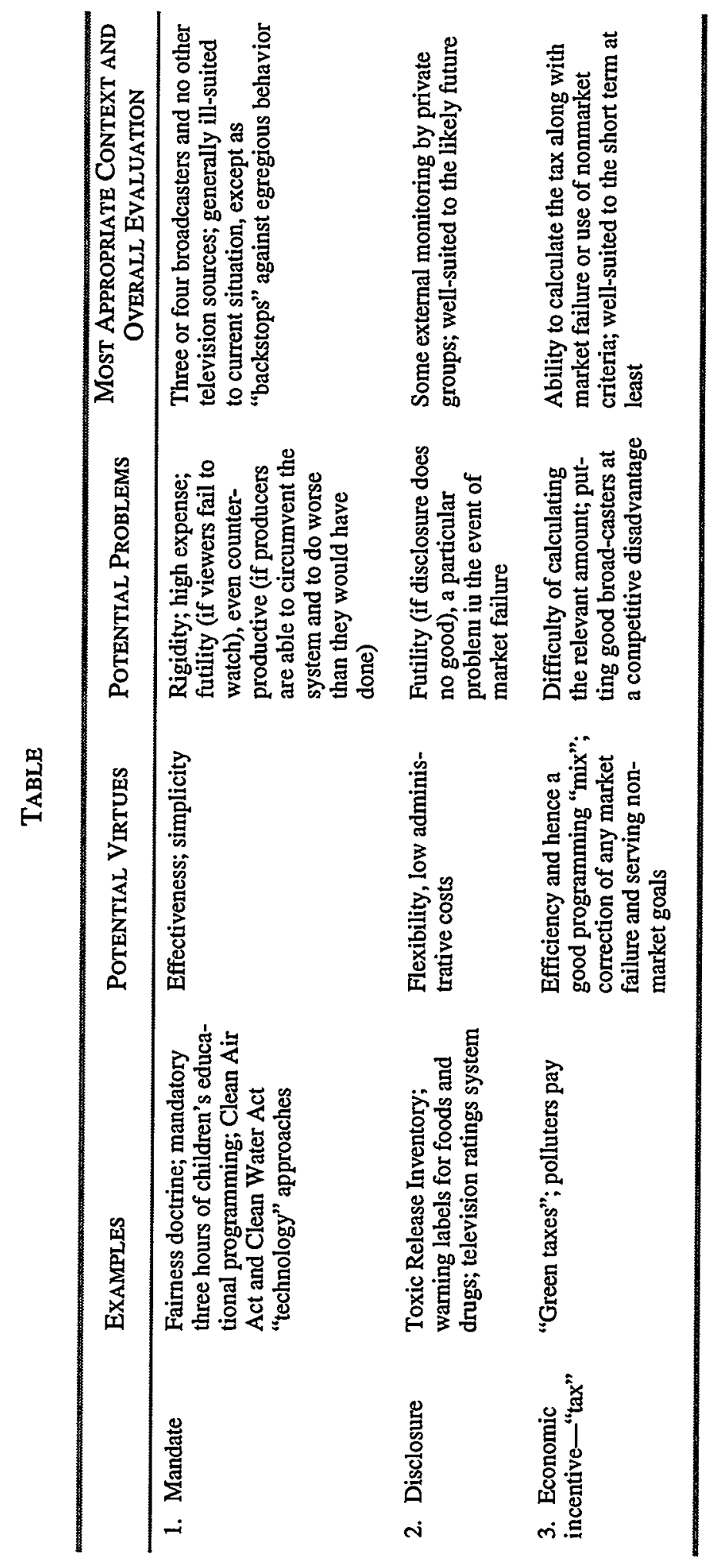




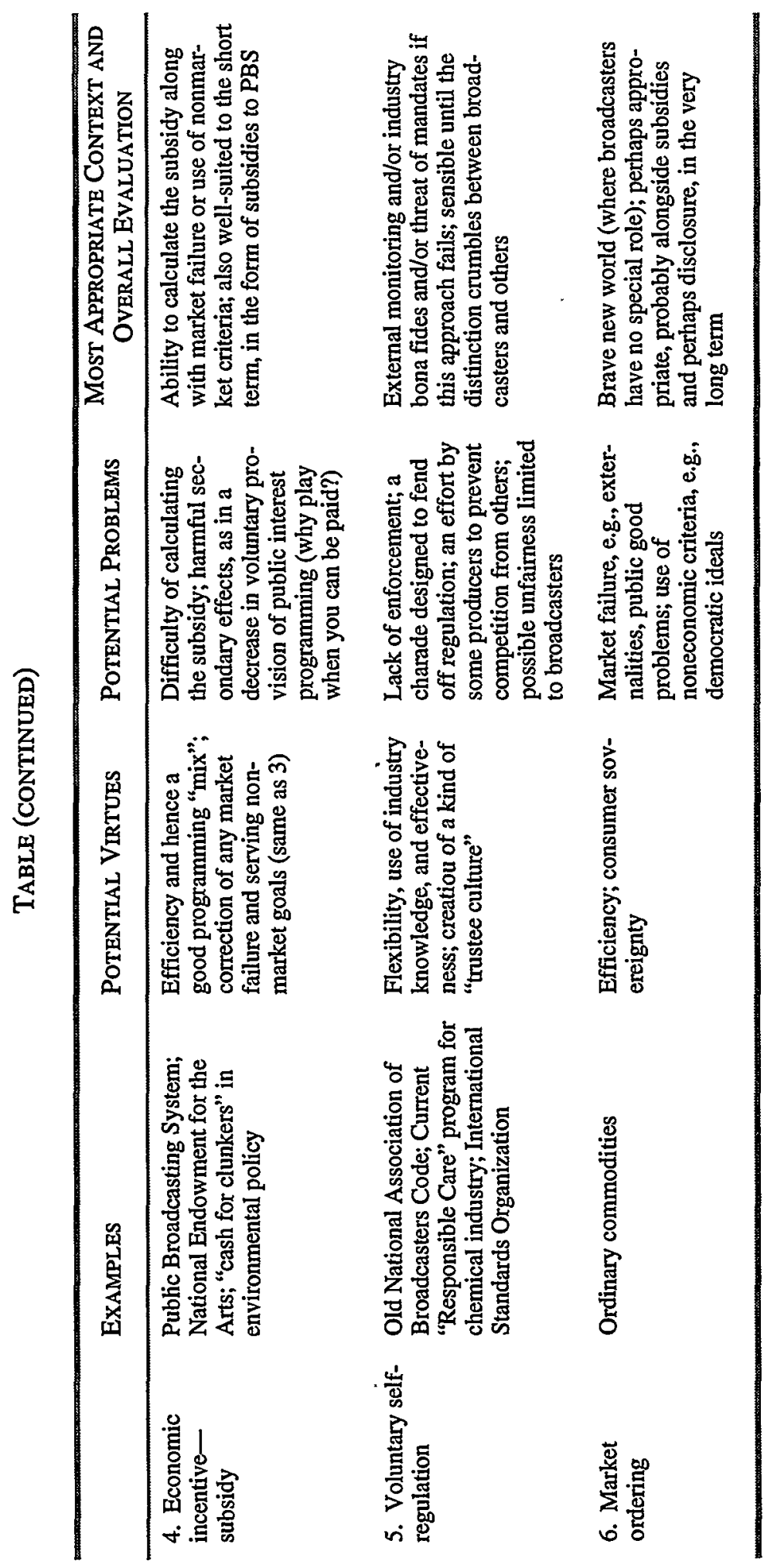


Some of these tools could serve as complements rather than as alternatives. Disclosure makes sense with or without additional strategies. It should be the least controversial item on the list; the only real question is what else should accompany it. Disclosure is likely to work especially well in tandem with voluntary self-regulation, indeed the two tools are natural allies. By contrast, mandates and economic incentives are genuine competitors, and in the current context, economic incentives generally seem best, with mandates operating as a "backstop," probably to be eliminated in the long term. . $^{24}$

As I have emphasized, these recommendations are designed for the current stage of telecommunications technology; they are also likely to make sense for the near term. For the next decade, the key question is whether imitiatives designed for broadcasters should be applied to cable programmers as well (especially disclosure and compliance with a code). In the very long term, when broadcasters occupy no special role, it may be best to impose disclosure requireinents on general-interest stations, and also to subsidize high-quality programming of various sorts. A reasonable conclusion would be that in the long-term, public interest programming will be best promoted via subsidies, not through regulation of any kind. In such an era, much will have been gained and much will also have been lost, with the fragmentation of the television market, with less in the way of common experiences, and, possibly, with less frequent exposure to serious coverage of serious issues. ${ }^{242}$ It is too soon to know whether the very long term will coine in the next decade or long thereafter. ${ }^{243}$

One fimal note: The discussion here has been focused on law, not on norms or culture; but the argument for a certain conception of the social role of television bears at least as inuch on norms and culture as on law. It is possible to think that before long, it will not make sense to impose regulatory requirements on $\mathrm{CBS}, \mathrm{NBC}, \mathrm{ABC}$, and $\mathrm{Fox}$, any more than it makes sense to impose regulatory requirements on Newsweek, Time, The New York Times, USA Today, National Review, or The New Republic. I have argued against this conclusion, but it must be taken seriously. Even if it is accepted, it is crucial to say that those who provide television, like those who produce newspapers and magazines, have a distinctive cultural responsibility, associated with the promotion of a democratic culture. Many people not subject to regulation take this responsibility seriously; many do not. If law diminishes as a constraining force, it is all the more important to speak on behalf of the basic norms-protection of children,

241. For an overlapping discussion, emphasizing the value of "industry mixes" in the context of environmental law, see GUNNINGHAM ET AL., supra note 20, at 422-48.

242. See LESSIG, supra note 66, at 185-86.

243. See OwEN, supra note 3, at 311-26 (predicting that convergence will take a long time, with the suggestion that the Internet may never become an important means of delivering television). 
serious attention to serious issues, inclusion of a wide variety of social groups, including the hearing impaired-that have undergirded regulatory law in the past. If it flourishes, a "trustee culture" can do much of the work of the law.

\section{CONCLUSION}

Much of the discussion here has involved appropriate regulatory tools. For the most part, the policy imstruments of choice slould not involve rigid dictates or commands, which are expensive and potentially counterproductive, and in any case ill-suited to an era of rapidly changing technology. I have suggested a strong preference for the less intrusive options of disclosure, economic incentives, and voluntary self-regulation. Disclosure has been a surprisingly successful, low-cost strategy in other areas of regulatory law. If certain broadcasting is seen as a public good, analogous to clean air, economic incentives may be able to accomplish a good deal, and to do so at relatively low cost. Because competitive pressures are frequently the engine behind poor broadcaster performance, voluntary selfregulation may turn out to be a desirable kind of "cartel," helping to counteract short-term interests. Through this route it may be possible to develop an intermediate system of controls, responding to the market and nonmarket failures of current inarkets, but without introducing the rigidity and inefficiencies of command-and-control regulation. These points hold notwithstanding current and anticipated technological developments. ${ }^{244}$ Of course, the appropriate attitude toward such instruments is praginatic, empirical, and experimental, rather than dogmatic or theological. If these instruments fail to work, it will be worthwhile to consider alternatives.

If ineasures of this kind have promise in the areas of environmental protection and public interest programming, there is every reason to explore them in other, less familiar contexts as well. In inany areas of law, command-and-control regulation has proved a partial or complete failure, and the natural alternative-a system of well-defined property rights and freedom of contract-may produce serious problems of its own. In such circumstances, any "third way," if it is ultimately to develop for the modern regulatory state, is likely to place heavy reliance on disclosure, economic incentives, and voluntary self-regulation.

244. See Goldberg et al., supra note 5, at 296 (footnote omitted), arguing that:

A further point of some importance is that there is no single new media form or market, and there is never likely to be such uniformity. Markets remain distinct; for example there is still a clear distinction between television-type services and on-line services. Technological convergence may be imminent in the form of television Internet access (or Web TV) becoming cheaply available, but the cultures remain radically different. Indeed, im the context of television, it seems likely that, though delivery forms may change, the culture may not, and that new types of media may supplement rather than replace existing ones. Again the message is one of caution before we scrap existing regulatory arrangements. 
The most fundamental points mvolve the appropriate understanding of a system of free expression-an understanding of what gives such a system its motivation and point. I have einphasized the external benefits that come from public interest programming and also the peculiar characteristics of the television market, where viewers, or eyeballs, are a commodity provided to advertisers. Because of the collective action problem, regulatory efforts that attempt to promote democratic goals, or that provide captioning for the hearing impaired, are easily defended in principle. But I have also argued that purely econoimic principles should be rejected as the foundation for communications policy. With respect to public imterest programming, viewers' tastes nuay be a product of an undesirable set of communications options, and in their capacity as citizens, people may well want to make things better rather than worse. Especially in light of the role of the communications media in the production of culture-and on both preferences and values - it is entirely legitimate for a democratic governinent to refuse to nuake "consumption choices" the exclusive basis for policy design. I have enuphasized that a public committed to deliberative democracy 1might well support initiatives designed to provide better programming for children and better coverage of public issues. ${ }^{245}$ So long as they are subject to democratic control, such initiatives should be regarded not as a paternalistic interference with private choices by a regulatory elite, but as an effort by a self-governing public to proniote a political culture that is consistent with its own highest aspirations. Above all, this is the sense in which there is a difference between the public imterest and what imterests the public.

245. See PRICE, supra note 9 , at $245-46$, for related conclusions. 